\title{
Białowieża Forest-A Relic of the High Naturalness of European Forests
}

\author{
Bogdan Jaroszewicz ${ }^{1} \mathbb{D}$, Olga Cholewińska ${ }^{1, * \mathbb{C}}$, Jerzy M. Gutowski ${ }^{2} \mathbb{D}$, Tomasz Samojlik $^{3} \mathbb{(}$, \\ Marcelina Zimny ${ }^{4}$ (D) and Małgorzata Latałowa ${ }^{4}$ (D) \\ 1 Białowieża Geobotanical Station, Faculty of Biology, University of Warsaw, Sportowa 19, 17-230 Białowieża, \\ Poland; b.jaroszewicz@uw.edu.pl \\ 2 Forest Research Institute, Department of Natural Forests, Park Dyrekcyjny 6, 17-230 Białowieża, Poland; \\ j.gutowski@ibles.waw.pl \\ 3 Mammal Research Institute, Polish Academy of Sciences, Stoczek 1, 17-230 Białowieża, Poland; \\ samojlik@ibs.bialowieza.pl \\ 4 Laboratory of Palaeoecology and Archaeoboatny, Department of Plant Ecology, Faculty of Biology, University of \\ Gdańsk, Wita Stwosza 59, 80-308 Gdańsk, Poland; m.zimny@ug.edu.pl (M.Z.); \\ malgorzata.latalowa@ug.edu.pl (M.L.) \\ * Correspondence: olga.cholewinska@uw.edu.pl; Tel.: +48-85-68-12-548
}

Received: 14 August 2019; Accepted: 27 September 2019; Published: 29 September 2019

\begin{abstract}
In Europe only some small isolated patches of forests with a high degree of naturalness still exist. These are forests, whose structure, composition and function has been shaped by natural dynamics without substantial anthropogenic influence over the long period. In this respect, Białowieża Forest is a unique location in Europe, with continuous forest cover for close to 12,000 years. The palynological, archaeological and historical data document only a weak anthropogenic fingerprint compared to other European lowland forests in Holocene history. Due to long-lasting protection, a large portion of the forest is still composed of stands originating from the pre-silvicultural period. Moreover, the stands of Białowieża Forest converted by silvicultural activities during the 20th century have the potential to recover owing to patches of stands with high naturalness, scattered throughout the forest. As conflict over management of the forest has recurred regularly for close to century, there is a need to summarize our knowledge on the forest history and natural assets, to help making scientifically informed decisions over its future. Expansion of a non-intervention approach to the Polish part of the forest is suggested to increase the stability of the entire ecosystem and enhance the chances for its successful adaptation to changing environmental conditions. This will increase the importance of Białowieża Forest as an open-door laboratory for biology, ecology, and forestry.
\end{abstract}

Keywords: Central European Lowland; ecological processes; environmental history; forest biodiversity; lowland natural forest; nature conservation; temperate forest dynamics

\section{Introduction}

We live in an era of globally accelerating loss of forests [1-3], which are essential ecosystems for life on Earth and for human well-being. Forests cover only one third of the land surface but contain $80 \%$ of the terrestrial plant biomass and provide habitat for over half of terrestrial biodiversity [4]. They sustain human well-being by delivering many ecosystem services [5-7]. For millennia forests were, and still are, of paramount importance for humankind and priority is still given to provisioning services, especially timber 
production, which causes loss of tree biomass and shrinking of forest cover in all wooded biomes [3]. Conversion of forests into other forms of land cover started thousands of years ago and during the past 5000 years global forest area has decreased by approximately 1.8 billion hectares, i.e., close to $50 \%$ of the area covered by forests today $[8,9]$. Since at least the late 1700 s, the vast majority of remaining European forests has been systematically changed by silvicultural practices [10]. In effect, only some small isolated patches of forests with a high degree of naturalness still exist in Europe, mainly in the least accessible and low populated mountain and boreal zones [11]. These are forests, whose structure, composition and function has been shaped by natural dynamics without substantial anthropogenic influence over the long period.

One of the very few lowland forest complexes on the European Plain, where substantial fragments of close-to-primeval forest have survived until our times, is Białowieża Forest (BF) [11]. Due to unique degree of naturalness, this forest is used as a benchmark by conservation science and modern forestry, and plays a role of a living laboratory for ecological, forestry and evolutionary sciences. Its importance to science is well reflected in high number of scientific articles mentioning the BF. At the end of June 2019 a search executed in the core collection of the Web of Science, with the keyword 'Bialowie" as a topic, returned 1087 articles (93 in 2018) which resulted in 20,697 citations (2309 in 2018). A large portion of these publications concentrate on interactions between components of the forest ecosystem, increasing our understanding of the "web of life". This web of connections cannot be studied in human-designed intensively managed forests because their functioning has been changed by depleted species composition [12,13], impoverished interactions $[14,15]$ and reduced amounts and diversity of substrates and microhabitats typical to natural forests [16,17]. Despite international recognition of the outstanding value of the BF [11,18], the year 2015 brought a relapse of the conflict over its management, ignited by an outbreak of European spruce bark beetle (Ips typographus L.) [19,20]. This conflict is not only an environmental one, but involves high political stakes on the country level [21]. To justify salvage logging of old-growths, politicians and decision makers involved into the conflict launched a disinformation campaign in the media, denying the uniqueness and natural character of the BF and stressing its cultural history and anthropogenic transformation instead [22,23]. The conflict became a global scientific issue and was listed by Nature as one of the most important science events globally that shaped the year 2017 [24].

Therefore, the aim of this paper is to summarize the multidisciplinary scientific evidence of the high natural value of the BF, which is not in opposition to the fact that the recent shape of this forest is indeed an effect of the long-lasting interplay between nature and its traditional extensive use. Specifically we want to: (1) Report the unique values of that last remnant of temperate close-to-natural forest; (2) outline the ecological and anthropogenic processes that shaped BF and allowed preservation of its high naturalness till the 21st century; (3) outline the century-long conflict over its management; (4) suggest some potential solutions in the field of its conservation.

\section{Methods}

We reviewed the published sources focusing on the environmental history, archeology, biodiversity, conservation status of the Białowieża Forest and conflicts over its management, which were used as a broad inclusion criteria. Our research questions were very broad and divergent, which made a classical systematic review approach not suitable, especially when some original palynological, faunistic and floristic data were included into the text, to close some minor knowledge gaps revealed during writing. In effect, our article is kind of a scoping review [25], expanded by the original data from the ongoing unpublished research. We used two different approaches to collate the evidence across this wide range of topics. In the fields of palaeoecology and environmental history, due to limited amount of papers considering BF, all articles in the field, from indexed and non-indexed sources were considered and their importance to the 
topic was assessed. In other fields of this review (ecology, biodiversity, nature conservation) the relevant literature was identified by searching the Web of Science (WoS) [26], using the key 'Bialowie*' as a topic, which returned 1087 articles (in 2019). In the next step we excluded categories of articles, which were: (1) Irrelevant to the scope of our review (e.g., mathematics applied, chemistry applied, immunology, ethics, tropical medicine, nutrition dietetics, agronomy, urban studies, veterinary studies, microbiology, etc.); (2) too broad or containing just case studies, species descriptions, etc. (e.g., zoology, ornithology, plant sciences, entomology, etc.). This filtering returned 440 articles, which importance to our review was assessed against the inclusion criteria based first on titles, thereafter the abstracts and finally, the full-text. Each author carried own assessment, according to the field of expertise. We also examined published bibliographies of BF [27-36], to identify sources not indexed in WoS and made a national (Polish) grey literature scanning for the last 4 years, for which a bibliography was not available. We used our expert knowledge on Białowieża Forest, gathered during scientific studies, to assess the importance of each publication against the inclusion criteria. We preferred in our review those papers or books, which summarized the knowledge in the field, over the papers concentrating on narrower subjects, single in-depth case studies, etc. In effect, we included 140 articles, books or website sources into the review: 42 Polish-language and 98 foreign language (English, Russian, Belarusian, German). Half of the sources (63 articles) were papers from the journals indexed in the WoS, while 33 articles were not listed. We cited also 38 books and 6 other sources (websites or manuscripts). Finally, the 61 articles selected for description of the wider background of the state of the art in conservation of natural forests in Europe and for discussing our findings, were chosen without any systematic approach, as is usually applied in the introduction and discussion chapters of the original scientific articles.

We are aware that our approach was biased by subjectivity of the final selection of the literature but any keyword allowed filtering off the less-important papers from those of high importance. Such decisions had to be based on expert knowledge and experience of the authors. However, none of the assessed articles on BF challenged its uniqueness in the country, continent or even world scale, and thus the risk that results of our review will be unbalanced is not high.

In the historical part of the paper we referred to published analyses instead of archival sources directly for two reasons: (1) The review character of this paper dictated focusing rather on already published studies than analyzing original documents, (2) the sheer number of historical sources relevant to the topic (several hundred documents from archives in Poland, Belarus, Russia, Ukraine, Lithuania, Germany and France) would make citing them directly in this paper impossible. We believe that referring to recently published and widely available works containing direct citations of archival sources made this paper more approachable for readers.

\section{Geographical and Geological Setting}

Białowieża Forest is an approximately $1500 \mathrm{~km}^{2}$ large forest complex stretching over the border between Poland and Belarus, in the eastern part of Central European Lowland (52 $41^{\prime} \mathrm{N} ; 3^{\circ} 49^{\prime}$ E; Figure 1). It covers a flat plain with numerous shallow river valleys and a system of depressions and hills. The altitude ranges from $134 \mathrm{~m}-140 \mathrm{~m}$ a.s.l. to $202 \mathrm{~m}$ a.s.l. The plain is a part of the larger moraine upland developed during retreat of the ice-sheet of the Warta Glaciation (isotopic Stage 6) [37]. The last glacial (Vistulian/Weichselian) ice-sheet did not cover the region, but periglacial processes resulted in covering older geological formations with younger sediments [38].

The ablation moraine built of sandy clays or clay sands and gravels dominates in the landscape. The second large formation is a bottom moraine built of a layer of clay tills several dozens of meters thick. These two main glacial formations were subject to aeolian and fluvial erosion, which resulted in formation of sandy plains and various types of inland dunes. In the Late Glacial and the Holocene, 
glacial melting depressions were filled with organic deposits [38], which are now a main source of palaeoecological information.

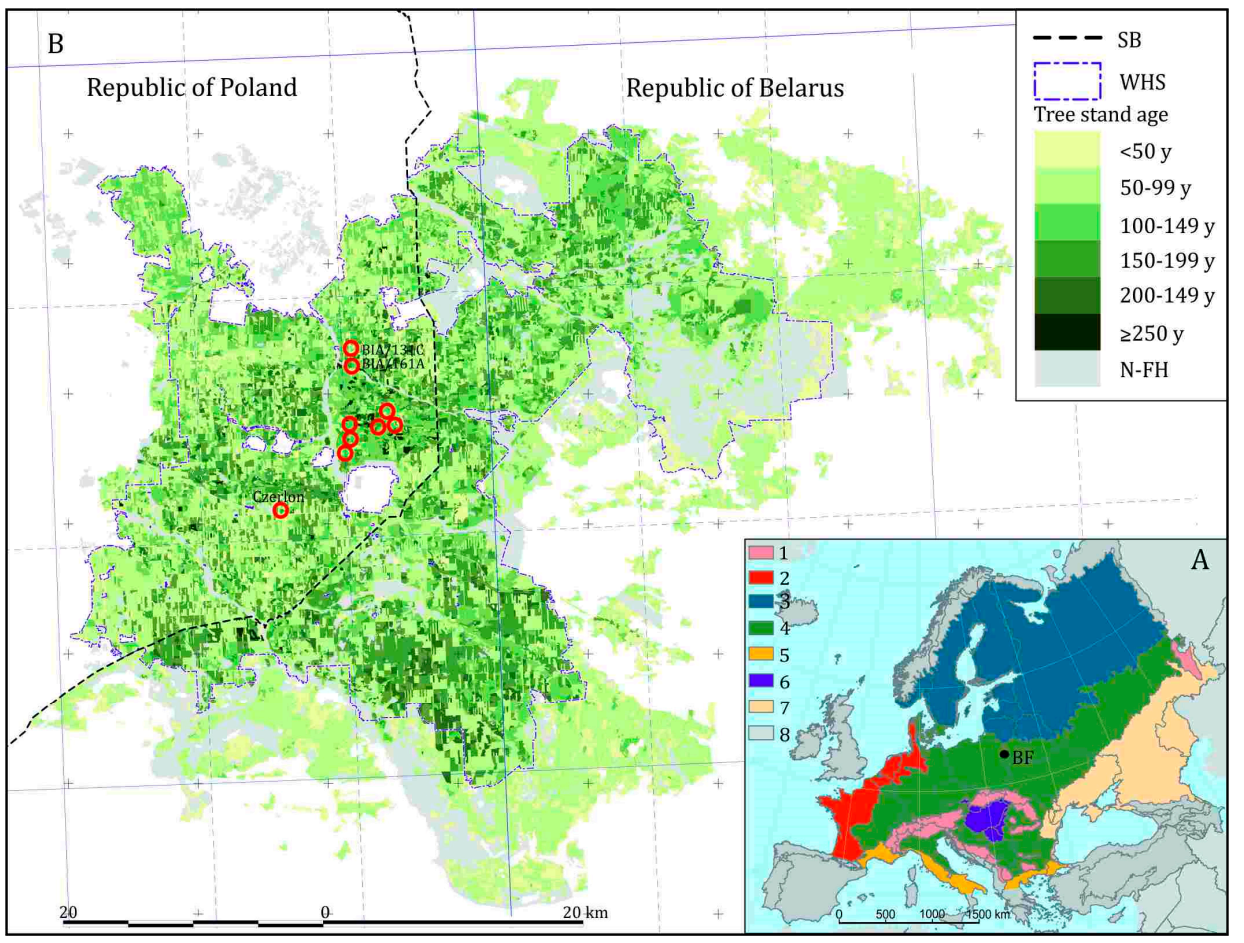

Figure 1. Biogeographic setting of Białowieża Forest. (A) Białowieża Forest (BF) on the background of the continental biogeographic regions of Europe [39]. Biogeographical regions: 1-Alpine; 2-Atlantic; 3-Boreal; 4-Continental; 5-Mediterranean; 6-Pannonian; 7-Macaronesia; 8-not covered. (B) Visualisation of the age of stands of Białowieża Forest (following 18, modified): SB—state border; WHS-border of the World Heritage Site "Białowieża Forest"; N-FH—non-forest habitats. Red circles denote recent palynological sampling sites, circles with names denote palynological sites used for analyses shown at Figures 2 and 3.

\subsection{Climate}

Białowieża Forest lies in the realm of a warm-summer humid continental climate [40]. Mean annual precipitation for the period 1950-2003 was $627.5 \mathrm{~mm}$, with extreme values of $434.5 \mathrm{~mm}$ in 1964 and 898.0 $\mathrm{mm}$ in 1974. Most of the precipitation $(391.1 \mathrm{~mm})$ comes during the May-October [41]. The mean snow cover period lasted for close to 80 days in 1950s, but declined to just 40 days in the last decade [42]. The mean annual temperature (MAT) for the same period was $6.8{ }^{\circ} \mathrm{C}$, with extreme values in $1996\left(5.0^{\circ} \mathrm{C}\right)$ and $1989\left(8.9^{\circ} \mathrm{C}\right)$. During the period $1950-2015$ the MAT increased by $1.27^{\circ} \mathrm{C}$ [43], with winter half-year warming much faster than the summer. Despite increasing temperatures and advancing spring [44], the length of the vegetation season did not change [41].

\subsection{Biogeography}

Białowieża Forest lies within the continental biogeographical region [39] (Figure 1), the zone of hemiboreal, nemoral coniferous and mixed broadleaved-coniferous forests [45]. This is reflected in the species composition of the BF stands, which stand out from West European forests by a lack of beech (Fagus sylvatica L.) and sycamore maple (Acer pseudoplatanus L.). From East European forests it differs by 
high share of English oak (Quercus robur L.), European hornbeam (Carpinus betulus L.) and small-leaved lime (Tilia cordata Mill.). The high share of Norway spruce (Picea abies (L.) H. Karst.), present in almost all forest communities, makes BF similar to the forests of north-eastern Europe [46]. There are also many animal, plant and fungi species, which reach in the region of BF their geographical northern, southern or eastern range limits. Many boreal and boreo-montane biogeographic elements inhabit the forest, e.g., taiga tick (Ixodes persulcatus Schulze), beetles Rhacopus attenuatus Maeklin and Lacon lepidopterus Panzer, bumble bee Bombus schrencki Morawitz, mosquito Aedes pullatus Coquillet [47], blue hare (Lepus timidus L.), and Laxman's shrew (Sorex caecutiens Laxmann) [48]. Boreal distribution is characteristic also for several plant species, e.g., Linnea borealis L. or Goodyera repens (L.) R. Br. [49] and fungi species, e.g., Antrodia sitchensis (D. V. Baxter), Boreostereum radiatum (Peck) Parmasto, Fomitopsis rosea (Alb. and Schwein.), Vararia borealis Pouzar [50]. On the other hand, there are several species of a southern, Pontic, or sub-Pontic character, which prefer warm and dry continental or submediterranean climates both among plants, e.g., Glechoma hirsuta (Waldst. and Kit.), Evonymus verrucosus Scop. [49] and fauna, e.g., beetles: Clytus tropicus (Panzer) and Deilus fugax Oliv. [51] and Agrilus antiquus Muls. [52].

\section{Naturalness and Biodiversity}

A large portion of the BF meets the conditions of forest naturalness "undisturbed by humans" as defined by the European Environmental Agency (EEA) [45], which is in contrast to the forests of adjacent regions, which occupy mostly post-agricultural land and were designed and planted, and fell into the category of "semi-natural forests". The EEA conditions describing the forest undisturbed by humans are: (1) Natural forest dynamics reflected by natural tree composition, occurrence of dead wood, natural age structure, and natural regeneration processes; (2) the area large enough to maintain its natural characteristics; (3) the last significant human intervention long enough ago to allow re-establishment the natural composition of species and processes. The BF forests meet these three conditions by displaying many features typical of natural forests. (1) It is one of the biggest forest complexes on the European Plain, with high ecosystem integrity $[11,18,46]$ and relatively good connectivity with other forests at least towards the east and north [53]. (2) Its vegetation is close to the potential vegetation, which would cover the area if humans had not interfered [54]. (3) Large portions of BF are still shaped by natural disturbances, especially by insect outbreaks, windthrows, and windbreaks, without the interference of humans $[11,46,55,56]$. (4) Long-lasting continuous forest cover, combined with a low level of colonization and anthropogenic activities [57], allows the assumption that downed and standing deadwood has been present there incessantly for millennia. (5) The density of large old trees, especially within the limits of the Polish Białowieża National Park (PL BNP), and of hollow and veteran trees is outstandingly high there [58,59]. (6) The share of old-growths older than 100 years (Figure 1B)—originated before the introduction of modern forestry to BF-is very high $[18,60]$. (7) In effect, BF hosts extremely high species richness (for a European temperate lowland forest) of all forest taxonomic groups, especially forest birds [61], insects [47,55], macrofungi [62], and lichens [63] (Table 1). (8) The forest hosts a high number of ancient forest plant species sensu Hermy [64] and many relic species of natural forests among invertebrates, lichens, and fungi $[63,65,66]$. (9) The low level of conversion of natural communities [54] is expressed in the relatively low share of non-forest species of birds [67] and plants [68] in the ecosystem. (10) The mammal community is close-to-complete for the Central European Lowland [69], including the most numerous population of European bison Bison bonasus L. in the World and high ecological importance of big predators, especially grey wolf Canis lupus L. and European lynx Lynx lynx L. [70]. (11) Many species exhibit primeval behaviour, e.g., common swift Apus apus L. nests on large dead oak trees, predators considered nowadays as open area specialists, like the common buzzard Buteo buteo L., hunt under the forest canopy, etc. [71]. 
Table 1. Species richness of some taxonomic groups of organisms of Białowieża Forest $\left(1500 \mathrm{~km}^{2}\right)$ on the background of species richness of Poland $\left(312,700 \mathrm{~km}^{2}\right)$ and the United Nations Educational, Scientific and Cultural Organization (UNESCO) forest world heritage sites from Palearctic and Nearctic, for which published data was available. BF—Białowieża Forest, NP—National Park, "-"—data not available. Source of data: [18,47].

\begin{tabular}{|c|c|c|c|c|c|c|c|c|}
\hline \multirow[t]{2}{*}{ Taxonomic Group } & $\begin{array}{c}\text { BF } \\
1500 \mathrm{~km}^{2}\end{array}$ & $\begin{array}{c}\text { Poland } \\
312,700 \mathrm{~km}^{2}\end{array}$ & $\begin{array}{c}\text { Central Sichote } \\
\text { Alin } \\
15,539 \mathrm{~km}^{2}\end{array}$ & $\begin{array}{c}\text { Great Smoky } \\
\text { Mts. } \\
2090 \text { km }^{2}\end{array}$ & $\begin{array}{c}\text { Mount } \\
\text { Huangshan } \\
154 \mathrm{~km}^{2}\end{array}$ & $\begin{array}{c}\text { Wood Buffalo NP } \\
44,800 \mathrm{~km}^{2}\end{array}$ & $\begin{array}{c}\text { Yellow-Stone NP } \\
8983 \mathrm{~km}^{2}\end{array}$ & $\begin{array}{c}\text { Fenglin Nature } \\
\text { Reserve } \\
184 \text { km }^{2}\end{array}$ \\
\hline & \multicolumn{8}{|c|}{ Number of Species } \\
\hline Animals & 12,000 & 40,000 & - & - & - & - & - & - \\
\hline Birds & 250 & 454 & 370 & 240 & 170 & 226 & 311 & 220 \\
\hline Mammals & 59 & 117 & 71 & 66 & 48 & 47 & 67 & 52 \\
\hline Insects & 9600 & 28,000 & - & - & - & - & - & - \\
\hline Beetles & 3199 & - & - & 2518 & - & - & - & - \\
\hline Plants & 1280 & 3438 & - & - & - & - & - & - \\
\hline Vascular plants & 1070 & 2491 & 1200 & 1450 & $1650^{*}$ & - & 1700 & 568 \\
\hline Bryophytes & 263 & 947 & - & - & - & - & - & - \\
\hline Fungi & 3398 & 11,000 & - & - & - & - & - & - \\
\hline Macrofungi & 1998 & 3200 & - & - & - & - & - & - \\
\hline Polypores & 210 & 240 & - & - & - & - & - & 161 \\
\hline Microfungi & 1400 & 6000 & - & - & - & - & - & - \\
\hline Lichenicolous fungi & 50 & 240 & - & - & - & - & - & - \\
\hline Lichens & 500 & 1655 & 400 & 431 & $1650^{*}$ & - & 186 & - \\
\hline
\end{tabular}

* The total number of vascular plants and lichens together. 


\subsection{Habitats}

The BF is a mosaic of habitats (abiotic conditions) covered by an overlapping mosaic of forest vegetation ordered in accordance with a natural toposequence: From floodplain forests in the river valleys to mesic pine forests at the tops of sandy hills [46]. Natural toposequences have gone in many European forests, mainly due to the homogenisation of habitats resulting from intensive silviculture. In the western (Polish) part of BF forest communities cover about $96 \%$ of the area [72], while in the eastern (Belarussian) part their cover is about $90 \%$ [18]. Completely different classification of vegetation types used in western and eastern part does not allow a common characterization of the habitat structure. Very roughly, over $50 \%$ of the western part of BF is covered by the mesic and mesotrophic habitats of mixed deciduous forests, which potentially should be covered by oak-lime-hornbeam forest (Tilio-Carpinetum)—an unevenly aged, multi-species and multi-layered deciduous forest with a high share of $C$. betulus, $Q$. robur, Acer platanoides L. and T. cordata [72]. The eastern part is covered by close to $60 \%$ in poorer and drier habitats of coniferous, mostly pine forests. In spite of the very clear difference in habitat cover, the share of stands dominated by conifers is very high in both parts ( $55.1 \%$ vs. $68.7 \%$ in the western and eastern part, respectively; Table 2$)$, which reflects conversion of natural ecosystems by forest management during the last century, with replacement of mixed deciduous forests by Scots pine Pinus sylvestris L. and Norway spruce plantations, especially in the western part of BF.

Table 2. Share (\%) of the main tree species (according to tree species prevailing in the stand) in Białowieża Forest in the western (Polish—as of 2001) and eastern (Belarussian—as of 2005) part. Source of data: [18].

\begin{tabular}{ccc}
\hline Tree Species & Western Part & Eastern Part \\
\hline Scots pine Pinus sylvestris & 28.3 & 58.0 \\
Norway spruce Picea abies & 26.8 & 10.7 \\
Black alder Alnus glutinosa & 20.0 & 15.3 \\
English oak Quercus robur & 11.0 & 4.7 \\
Silver birch Betula pendula & 8.3 & 8.3 \\
and Downy birch Betula pubescens & 2.2 & 1.0 \\
Hornbeam Carpinus betulus & 2.2 & 1.1 \\
European ash Fraxinus excelsior & 0.7 & 0.8 \\
Aspen Populus tremula & 0.5 & 0.1 \\
Other (small-leaved lime Tilia cordata, Norway & & \\
maple Acer platanoides, Ulmus sp., Salix sp.) & &
\end{tabular}

The heterogeneity of habitats is increased by the diversity of microhabitats typical to natural forests: Deadwood, broken and uprooted trees, tree cavities, fruiting bodies of fungi, animal carcasses, etc. The average amount of deadwood in the strictly protected core area of PL BNP is close to $159 \mathrm{~m}^{3} \mathrm{ha}^{-1}\left(50.1( \pm 4.5) \mathrm{m}^{3} \mathrm{ha}^{-1}\right.$ of standing dead trees and $108.4( \pm 5.3) \mathrm{m}^{3} \mathrm{ha}^{-1}$ of downed coarse woody debris). At the same time the average standing wood volume of living trees is $472.5( \pm 11.8) \mathrm{m}^{3} \mathrm{ha}^{-1}$ [73]. It supports especially diversity rare cryptogams [74], macrofungi [50] and plays some role in maintaining vascular plant populations [75]. Presence of microhabitats typical to natural forests is very important also for animals: $30 \%$ to $50 \%$ of the animal species are saproxylophilic, i.e., associated with deadwood [55]. Even birds are very dependent on structures typical to natural forests-species composition of their communities depends more on microhabitat availability than on tree species composition of stands (deciduous vs. coniferous) [76]. 


\subsection{Species}

The mosaic of different environmental niches, e.g., local ground depressions, root systems of uprooted trees, deadwood in diverse stages of decay, etc., and microniches, e.g., fruiting bodies of tree-growing fungi, tree holes, dead branches, etc., favours high biodiversity [17]. The data on flora and fauna of BF has been gathered since the turn of the 18th and 19th centuries, when the first scientific papers, based on materials collected in the forest, were published $[77,78]$. During the last century, aside of continuation of floristic and faunistic surveys, over 100 species new to science, mainly fungi and insects, were described from there [79] — and still almost every year new taxons are added [80-82]. Out of the vast diversity of life, only data on plants, macrofungi (including lichens) and animals is robust enough to carry out synthesis or comparison to similar temperate forests of Northern Hemisphere, showing the BF outstanding diversity (Table 1).

Flora of BF vascular plants comprises 1070 species, including approximately 670 forest species and close to 400 synanthropic ones [68]. However, the recent real number is much higher, as there are another at least half thousand alien species cultivated in and around of the forest, with many spontaneously dispersing and surviving in the wild [83] (Adamowski, unpubl.). Non-vascular plants are less numerous: There are 200 species of mosses, 63 species of liverworts [66] and one hornwort (Wierzcholska, unpubl.) registered up-to-date, however, the knowledge on these three groups in BF was never critically revised.

$\mathrm{BF}$ is one of the most important hotspots of fungal biodiversity both in Poland and Europe [50] (Table 1). Faliński and Mułenko [84] reported close to 1380 fungi and 164 lichen species from only a 144 ha study plot in the Strict Reserve of the PL BNP. The estimated number of fungi in the whole BF probably exceeds 5000 species, of which 1998 taxons of macrofungi has been registered by 2018 [62] and over 500 species of lichens and close to 50 species of associated with them lichenicolous fungi [63] (Table 1). There are many highly endangered or threatened species in this group, and almost 200 species are unknown from other sites in Poland [63]. Some species were described from there as new for science (e.g., Dentipratulum bialoviesense Domański) and found only in very few other sites [85]. Among the European forests, the BF is distinguished also by the richness of polyporoidal fungi. Out of 394 species, known in Europe, 210 polypores were recorded in BF. This is close to $90 \%$ of the species of this taxonomic group known from Poland [86] (Table 1).

The critical revision of the knowledge on fauna of BF revealed over 11,564 thousand animal species [47] (Table 1) - a number which can't be found anywhere else in forests of a comparable size in Europe [55] (Table 1). The last two decades brought records of several hundred species new to the forest (mainly insects), thus, the real number exceeded 12 thousands [Jaroszewicz, unpubl.]. Forest invertebrates, especially saproxylic, are the most valuable component of the fauna of the $\mathrm{BF}$, since many species that have survived here, are extinct or occur only in small, isolated populations in other regions. Just among the beetles alone, over 1000 saproxylic species are recorded, with many relic (primeval) species-typical of natural forests. $\mathrm{BF}$ is the most important refuge for primeval forest entomofauna in the European lowlands $[47,55,87]$. Even among the vertebrates, the best studied taxonomic group of animals of BF [47], there are several species, which had extinct in most of European forests or are limited only to those with high degree of naturalness: European bison, Laxman's shrew, white-backed woodpecker (Dendrocopos leucotos Bechst.) or Eurasian three-toed woodpecker (Picoides tridactilus L.), to name just the most charismatic.

\subsection{Ecological Processes}

The course and intensity of ecological processes differ depending on ecosystem biodiversity, species composition, structure, environmental context, historical land use and recent human interference [88-90]. In effect ecosystems with a high level of naturalness are driven by different dynamics than those heavily modified by human activities [91-93]. In BF, natural processes, undisturbed or just moderately modified 
by direct human interference, can be observed on a large portion of territory. The long-term continuity of ecological processes is an important, however poorly understood, factor [94].

One of the unique features of BF ecosystems is that soil formation has been only locally disturbed by humans [95]. Over large areas the top layer of soil has not been disturbed by agricultural or silvicultural ploughing, i.e., its formation has been continuous for several centuries or even millennia [96]. Soil formation in a natural forest is influenced by animal activities (e.g., wild boar (Sus scrofa L.) rooting, rodent burrowing), the presence of deadwood and tree uprooting. Especially the latter modifies not just the soil but also creates completely new microhabitats: naked soil, humus heaps, soil micro-relief, etc [17]. This process strongly modifies the distribution and local abundance of understorey species, increasing the heterogeneity of their communities [46].

The BF is very special for the completeness of the life cycles of trees: from seedlings to individuals dying due to advanced age and giant size-a situation rare in the rest of Europe [11] and globally [97-99]. However, not just single trees, but in many forest patches, whole stands develop and die in a full natural forest life cycle, from regeneration to their terminal phase, with temporarily occurring open spaces. These processes are accompanied by natural regenerative succession-new assemblages of species develop in places where they previously declined due to gradual changes in the environment or in effect of natural disturbances [46,100,101].

Other outstanding processes of the BF are fluxes of nutrients and energy. This includes cycles of synchronized masting years of trees, which induce oscillations in rodent abundance [102,103] and increase the winter survival of large herbivores $[70,104]$. The other examples are cycles of insect outbreaks, e.g., Ips typographus [105] or winter moth Operophtera brumata L., causing defoliation or even the death of trees. This in turn changes the amount of light reaching the forest floor and increases the availability of nutrients, which influences forest floor vegetation but also the breeding success of forest birds [106].

The course and dynamics of ecological processes are very important in the light of the recent climate change, as they adjust ecosystems to new conditions by changing species abundance and distribution in space, which leads to a reassembling of species communities and networks of interactions between species. On the other hand, climate warming brings modification of the course, frequency and intensity of natural processes, leading to their increase [107] or decline [108], which influences the rules of ecosystem assembly.

\section{Environmental History}

The current diversity of the BF is an effect of the natural processes and interactions between nature and humans. Thus, knowledge of the environmental history is essential for understanding of the current state of the ecosystem, as land use legacies influence soil conditions, tree growth, understory vegetation and many other forest characteristics [109-111]. However, until recently, the Holocene history of BF was little known, even if palynologists have been interested in this area for several decades [112-116]. Poor stratigraphic and taxonomic resolution of the pollen analyses and a lack of radiocarbon dating are the main limitations of the results of these works with regard to modern standards in palaeoecology. In turn, the study by Mitchell and Cole [117] who analyzed two short profiles from forest hollows, was specifically focused on the last 1300 years of succession patterns in the mixed deciduous Tilio-Carpinetum and mixed coniferous Pino-Quercetum forest communities. Only recently, multiple coring has been done in Strict Reserve of PL BNP [118-120] and outside the Park [57]. In the present paper we present selected results of pollen analysis performed in three sites (Figure 1B).

\subsection{Holocene Forest History until the Medieval Period}

Having regard to differences in species diversity resulting from geographical location, i.e., distance from glacial refugia, dispersal barriers, and climatic parameters influencing migration patterns and the 
evolution of distribution ranges of tree species in Europe [121,122], the general features of the early and mid-Holocene history of BF and the timing of the main stages in the forest's development follow well-known patterns in the post-glacial vegetation changes in the Central European Lowland (Figure 2A). This concerns Pinus and Betula dominated forests at the beginning of the Holocene and the subsequent expansion of Corylus at c. 10.8 ka [123,124], the Alnus expansion at c. $9.3 \mathrm{ka}$ [124], the formation of mixed deciduous forests between 9 and $8 \mathrm{ka}$, and their successive transformations since about $6 \mathrm{ka}[125,126]$.
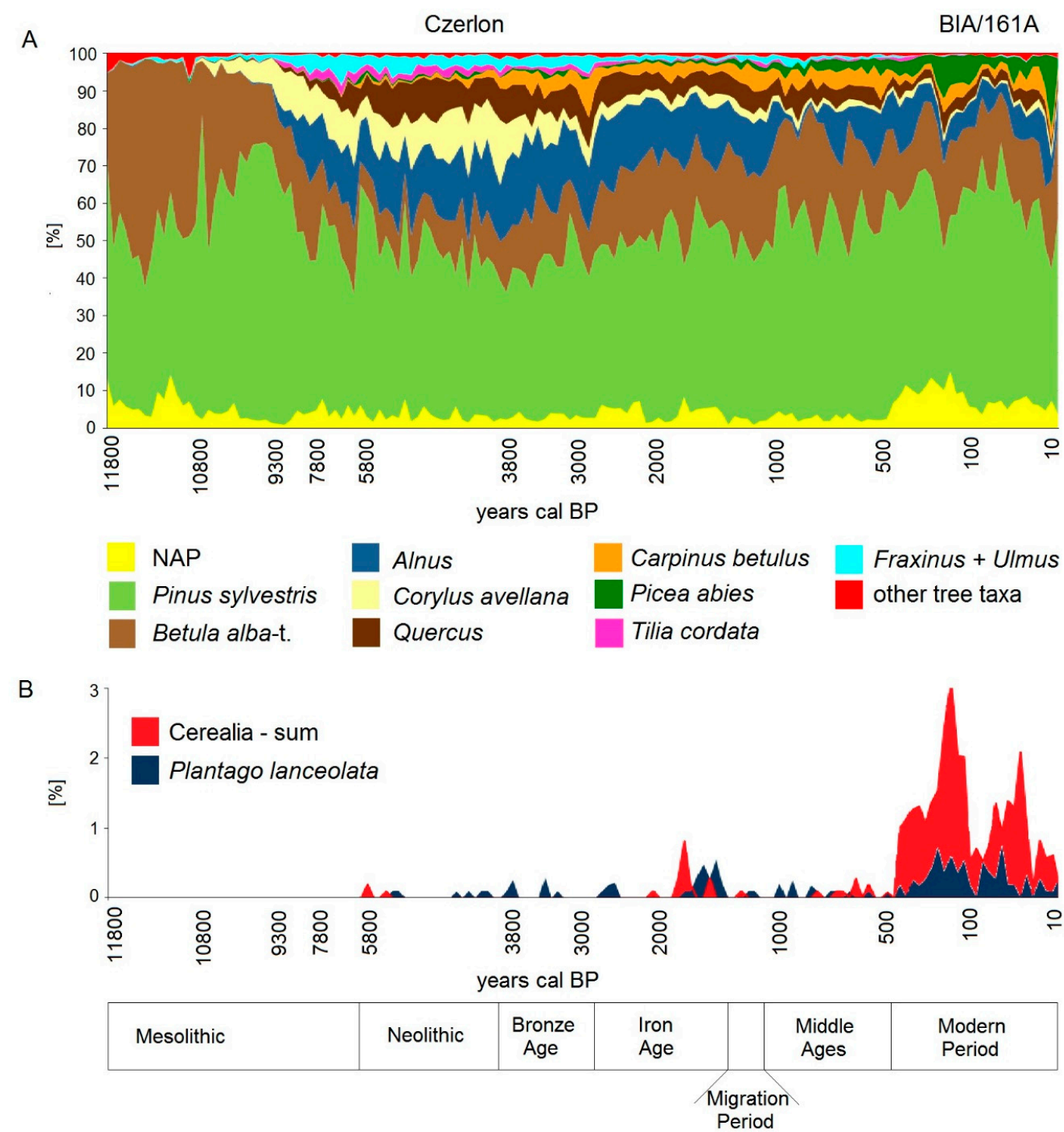

Figure 2. Combined palynological data from the Czerlon and BIA/161A sites (see Figure 1B), illustrating the Holocene history of Białowieża Forest: (A) Changes in the pollen proportions of the main tree taxa and non-arboreal pollen (NAP); (B) Changes in the pollen proportions of cereals and Plantago lanceolata against archaeological periodisation. The age scale is based on an OxCal age/depth model considering $14{ }^{14} \mathrm{C}$ dates. Source of the data: [57] (Pedziszewska and Zimny, unpubl.).

An important change in the forest communities at around $3.8 \mathrm{ka}$ concerned the strong decline of Corylus concurrent with expansion of Carpinus. The Corylus decline is a widely discussed palaeoecological event due to its apparent synchronicity over the European Plain. Climate change [124] or human impact [126] are 
considered as triggering factors diminishing the share of Corylus in European forests and the subsequent change in their taxonomic structure. It was around that time when the most characteristic of the present-day forest ecosystems of BF, the oak-lime-hornbeam forest (Tilio-Carpinetum type), developed. The specific feature of late Holocene BF history was the gradual expansion of Picea, which accelerated first at about 1.5 $\mathrm{ka}$ and then after $1 \mathrm{ka}$ following anthropogenic and natural forest disturbances, and climatic shifts [57,120]. Interestingly, the BF Picea population which forms the south-western limit of the species' present-day northern distribution range [127] stayed at a very low level for at least 5000 years and started to expand much later as compared to neighboring regions [128].

The pollen data revealed only weak agrarian activity in the Neolithic and the Bronze Age in the BF area (Figure 2B), expressed in slight declines in deciduous tree pollen, the appearance of single cereal (Cerealia-type and Hordeum-type) pollen and the scattered pollen of weed and pasture plants, e.g., Plantago lanceolata L. considered as a palynological indicator of primitive agriculture and animal husbandry [129]. This is in line with the low number of archaeological sites for the typical farmer's cultures in the BF area in the period between six and three thousand years BP recorded to date $[130,131]$.

In the period between 730-300 BC (the early Iron Age), the deciduous forest habitats were disturbed and openings within the forest were used for settlement and animal grazing as shown by increased proportions of the pollen of ruderal weeds and those typical for pastures. We may assume that also small-scale cultivation developed, but thus far palynological data has not recorded any pollen of cultivated plants for this period [57, Latałowa, unpubl.] which may be due to both too long distance to the nearest cultivated plots and poor pollen productivity and dispersal by the cultivated plants used in that period [cf. 129].

The second, distinct phase of human activity took place in the Late Roman Iron Age (c. AD 220-490). It left a pronounced palynological signature in all studied sites $[57,118,120]$ and archaeological structures and artifacts spread throughout the BF area $[118,132]$. Pollen data illustrate strong, though probably confined to several small areas, destruction of woodland, development of animal husbandry, and plant cultivation. Cereal cultivation is confirmed by the presence of Secale, Hordeum-type, and Triticum-type pollen while Cannabis sativa L. growing and retting has been confirmed by both pollen and seeds found in a former pond situated within the present-day Strict Reserve of the PL BNP $[57,118,120]$. Local forest destruction due to the development of metallurgy based on the local wood and bog iron ore resources has been also suggested [118] and confirmed by the archaeological finds of iron smelting furnaces and slag for both the early and late Iron Age cultures in the region [133-135].

After abandonment of the Iron Age settlements, the forest recovered on the earlier disturbed grounds, with $P$. abies among the species which expanded vigorously. For next several hundred years the BF was not extensively inhabited. Low frequency of anthropogenic indicators, including scattered pollen of cereals (mainly Secale) and P. lanceolata, suggests very limited use of this area up to about the 15th-16th century. The early Middle Ages and the high medieval period brought some colonization in different parts of BF, confirmed by archaeological investigations [summarized in 118] which, however, illustrate rather site-scale occupancy than a general scale of human impact on the BF area.

The above pollen-based reconstruction of the dynamics of settlement activity from prehistoric times to the medieval period conforms with the archaeological data. However, until recently the archaeological information from the present-day BF area was rather poor because of many restrictions concerning all nature destructive prospects in the protected areas. The new opportunities for discovery of material traces of former land use appeared when non-invasive methods, mainly aerial laser scanning/light detection and ranging (ALS/LIDAR) and geophysics surveys, were implemented for prospecting BF [136,137]. These non-invasive methods are especially effective there, because under patches of old-growth forest where for centuries soil was not disturbed by agricultural activities, traces of ancient human activity are extremely well preserved in comparison to the adjacent regions dominated by agriculture [134]. 


\subsection{High Medieval Period and Modern Times}

Studies of the BF's natural history in late medieval and modern times are strongly supported by existing historical documents, extracted during an extensive surveys in historical archives in Poland, Belarus, Russia, Lithuania, and Ukraine [138,139], and in already published sources [140-143]. The historical information compiled with archaeological traces left in the forest environment and the palynological imprint of settlement activity and forest use recorded in the sediments (Figure 3), enables rather detailed reconstruction of the BF history.
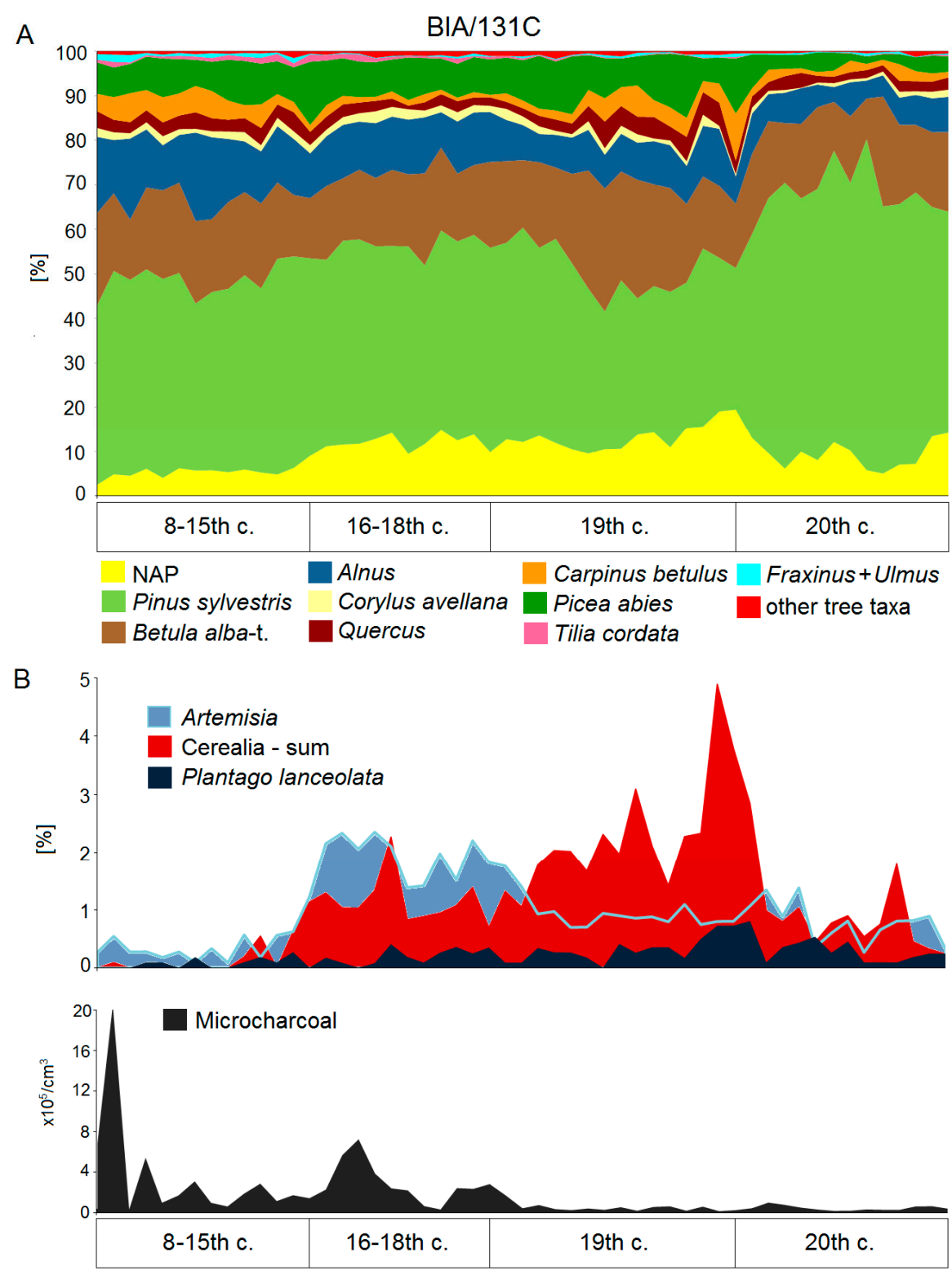

Figure 3. Selected palynological data from the BIA/131C site (see Figure 1B) illustrating BF history in the mediaeval and modern times: (A) Changes in the pollen proportions of the main tree taxa and non-arboreal pollen (NAP); (B) Changes in the pollen proportions of Artemisia, Cerealia (sum) and Plantago lanceolata, and concentration of microcharcoal particles in the sediments. The age scale is based on an OxCal age/depth model considering $8{ }^{14} \mathrm{C}$ dates and ${ }^{210} \mathrm{~Pb}$ dating. Source of the data: [120]. 
In the late mediaeval period, BF was the hereditary property of Lithuanian grand dukes [144], and had been a royal forest since the Polish-Lithuanian union of 1385. From that time until the end of the 18th century, BF was protected with the aim of preserving so called animalia superiora: European bison, brown bear Ursus arctos L., red deer Cervus elaphus L., and moose Alces alces L. for the purposes of royal hunts. However, between 1409 and 1784 fewer than 20 royal hunts have been confirmed by written sources [145] which implies that they had a rather limited impact on the forest's functioning and structure. The regulations of a royal forest dedicated to hunting included limitations untypical to other European or Polish forests of that period, which resulted in saving of its high degree of naturalness untill 20th century: Prohibition of settling in the forest as well as prohibition of hunting (apart from royal hunts) and commercial timber felling. The forest itself was surrounded by a ring of guard villages in which royal guards, riflemen, and beaters dwelled $[140,141]$. Royal hunting manors with accompanying settlements were the only exception to the rule of no settlements inside the forest until the second half of the 18th century [146].

The above restrictions did not prohibit traditional use of BF. Local villages, towns, and churches developing in the surrounding areas were granted 'royal access rights' to use precisely delimited parts of the forest (Figure 4). The majority of such rights included haymaking, i.e., permission to scythe forest meadows, usually along river valleys, remove hay from the forest or store it locally in meadows in haystacks till the winter. The second most important access right was the traditional bee-keeping: carving artificial beehives in tree trunks, attracting bees, and harvesting honey and wax. The third most important access right concerned construction of small dams on forest rivers, aimed at creating artificial flooded areas for fishing [139,147]. Unfortunately, due to disturbances in peat accumulation, the period between the 14th to 16th centuries is not well reflected in the pollen profiles. Persistent droughts recurring in the Middle Ages [148] were the most probable reason for temporary drying out of the peatbogs resulting in discontinuity of the pollen records. Nevertheless, in all the preserved sediment fragments representing that period, indicators of human activity occurred in very low frequencies confirming the historical information on the limited impact on the forest ecosystem and no or very weak local agricultural activity [118].

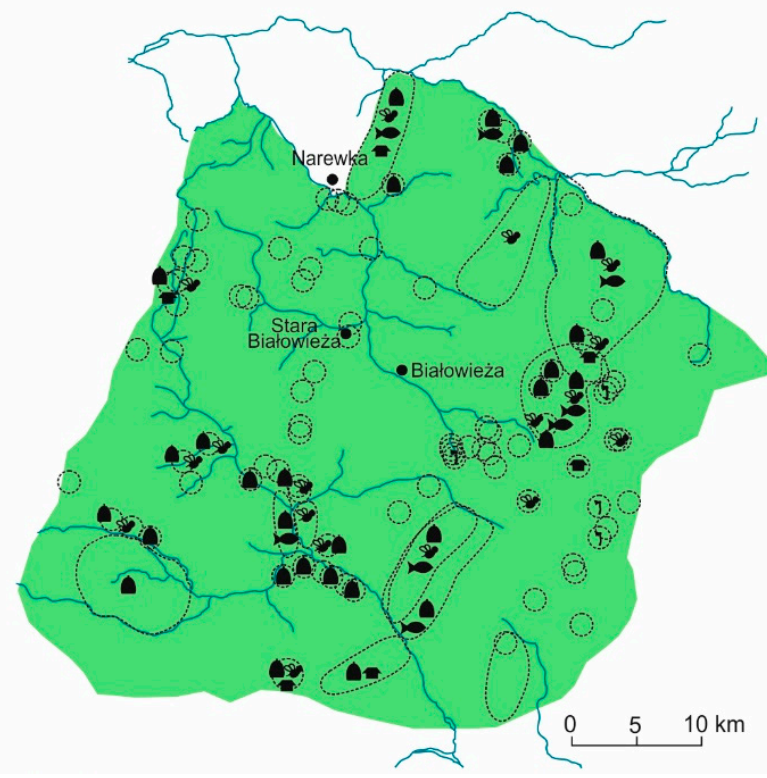

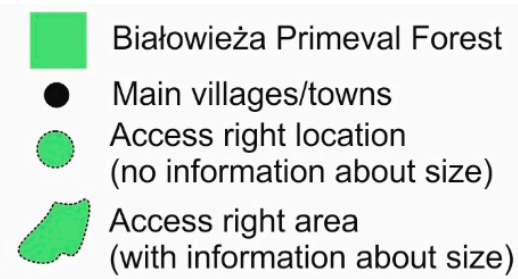

Access right types:

- Haymaking

Traditional bee-keeping

- River dams / fishing

1 Non-commercial timber for own use

- Cattle pasturing / shack building

Figure 4. Distribution of access areas in BF in the 15th-17th centuries based on historical sources (access areas of unknown size marked by a standard circle), with type of allowed utilization marked (only cases with known type of activity). 
In the 17th-18th centuries, new ways of forest use were introduced: Collection of bog iron ore in river valleys [135], charcoal burning [149], potash manufacturing [140,141,150], birch tar and pine tar production [138]. In the period 1765-1795, small-scale commercial timber extraction took place [140,141], with an average annual yield intensity estimated to $0.05-0.3 \mathrm{~m}^{3} \mathrm{ha}^{-1}$, and the establishment of associated new permanent villages and small ephemeral hamlets inside the forest to host specialised workers [138]. Dendrochronological research confirmed that in this period BF experienced frequent fires of low intensity and limited spatial extent [151]. This period left a distinct, very characteristic palynological imprint $[118,120]$ (Figure 3): Evidence of strong hornbeam decline and less distinct oak and lime declines. Spruce expanded on habitats of deciduous forests disturbed by human activities. The use of fire, reflected by high frequencies of microcharcoal particles, resulted in expansion of Calluna vulgaris (L.) Hull. Increased proportion of Artemisia pollen reflects ruderal vegetation which probably expanded in patches of disturbed forest. Small-scale agriculture activity is proven mainly by Secale pollen, while the small amount of pollen typical of open pastures (e.g., P. lanceolata) indicates that this form of land use was rather limited.

The next change was brought by the year 1795, when Poland lost its independence, and BF fell under Russian imperial rule. The Russian administration introduced a strict policy against fire, and banned potash and charcoal burning, construction of river dams and fish ponds, and extraction of bog iron ore. Traditional forest bee-keeping was gradually converted to household bee-keeping, and finally prohibited in the traditional form in 1888 [152,153]. Haymaking and forest livestock pasturing continued but was limited to the areas in the direct vicinity of villages [154], however, cattle grazing still had a significant negative effect on forest regeneration [155-157].

The Russian administration attempted to introduce large-scale logging, yet their efforts were limited and eventually marred by the lack of roads and conflict with the priority given to conservation of European bison [153,158]. In effect, although forest taxation was carried out and the forest was divided into compartments (in 1843-1846), timber exploitation was limited and interspersed with prolonged periods of prohibition on felling $[143,159]$. Until the end of the 19th century, all logged stands were left for natural regeneration. Artificial forest regeneration by sowing or planting was conducted only experimentally on some limited areas at the end of the century [159].

The impact of the 19th century management on BF is well reflected in pollen analysis $[118,120]$. The deciduous trees, mainly C. betulus and Quercus re-expanded, reaching a similar level as that in the medieval period. Also $P$. abies reinforced its position among the main forest components, mainly at the cost of pine. The decline of microcharcoal particles and the pollen of Artemisia indicates regeneration of the forest floor after the cessation of fires and previous forest utilisation. On the other hand, the small, concurrent increase of agriculture indicators is in line with the historical data indicating the gradual growth of settlement activity in BF during the 19th century $[46,160]$.

At the end of the 19th century and the beginning of the 20th century, BF ecosystems were significantly affected by high densities of game populations [46]. After the first tsar's hunt in 1860, BF was gradually transformed into an imperial game reserve, and in 1888 the entire BF became the private property of the tsar's family $[152,153]$. The new management aimed at maximizing game numbers through the extirpation of predators, supplementary feeding of game for up to six months per year in hundreds of feeding sites, the reintroduction of red deer (extinct in the 17th-18th century), and the introduction of alien fallow deer Dama dama L. and Siberian roe deer Capreolus pygargus Pallas [152,153,161]. The high density of ungulates had tremendous impact on tree recruitment, changing the proportion of tree species [162]. Due to high browsing pressure in oak-lime-hornbeam stands, the share of deciduous trees declined while spruce expanded [46], which several decades later, at the end of the 20th century, resulted in large-scale spruce die off on fertile habitats. The process has been recently accelerated by climate change and the resulting recurring I. typographus outbreaks allowing broadleaved tree stands to regenerate $[46,163,164]$. 


\section{The 20th and 21st Centuries: Silviculture versus Conservation}

The 20th century brought increasing threat to the BF natural ecosystems posed by logging, tree planting on cleared sites, and settlement development. At the same time, the legal protection of BF as a nature treasure started. During the First World War (WWI), mechanized timber exploitation was introduced for the first time to BF by the German army, with annual timber extraction in the period 1915-1918 estimated between $1.91 \mathrm{~m}^{3} \mathrm{ha}^{-1}$ [165] and $8.57 \mathrm{~m}^{3} \mathrm{ha}^{-1}$ [159]. In 1921, to preserve the most valuable, never-logged parts of $\mathrm{BF}$, the Polish government established the first nature reserve, the beginning of the recent PL BNP. Outside the reserve, in the years 1921-1939, commercial timber extraction was continued and forest stands were artificially replanted, mainly by Scots pine and Norway spruce [159]. During the Second World War (WWII), both Soviet (1939-1941) and German (1941-1944) occupants marked their presence in the area with timber extraction and parallel proclamation of a "reserve" dedicated to hunting [159]. The post-war era saw BF divided between Poland and the Belarusian Soviet Socialist Republic of the Union of Soviet Socialist Republics (Figure 1B). The majority of the Polish part stayed subject to regular forest management combined with protected enclaves scattered in the matrix of commercial stands. In 1947 the PL BNP was (re)established within limits similar to the pre-WWII reserve, and strict protection approach was applied on close to $90 \%$ of its area. In 1996 the area of the PL BNP was doubled to 10,517 ha, with strict protection expanded to 6059 ha. In the commercial part of the forest, the first nature reserve was established in 1961, and recently there are 21 nature reserves, covering 12,034 ha. Atop of this the whole Polish part of the BF is an area of landscape conservation (national level protected area (PA)), Natura 2000 site (European Community level PA) and global-level PAs: United Nations Educational, Scientific and Cultural Organization (UNESCO) Biosphere Reserve and the transboundary UNESCO World Heritage Site 'Białowieża Forest', encompassing western and eastern part of the forest.

Taking into account that in Polish part of BF competencies of several administrations (the national park, the regional directorate of environmental protection, the general directorate of environmental protection, the state forests, the local communes), with different management goals, overlap in the field, it had to lead to an outbreak of a conflict on management of the forest. This, during the period 2016-2018, involved international players (UNESCO and European Commission) and ended in the European Court of Justice, which in April 2018 banned logging in the forest due to the breaching of several articles of European Commission Bird and Habitat Directives [166]. This conflict, reignited by the outbreak of the spruce bark beetle, was not the first round of the struggle over BF management. The battle between advocates of nature conservation and supporters of silviculture started in 1921, with the establishment of the very first piece of protected area-the beginning of the recent PL BNP. The first conflict, similarly to nowadays, started due to the bark beetle outbreak management: the first warden (1923-1928) of the reserve, professor Józef Paczoski, was expelled from the position in 1928 by the Director of State Forests in Białowieża, due to accusations of "bringing the risk of disaster to forests by allowing development of bark beetles in the reserves" [167].

The Belarusian (Soviet till 1991) part of the Forest, since 1944 was managed as 'zapovednik' (the highest form of nature conservation in the Soviet Union) till 1956, then a state game reserve (1956-1991) and finally was converted into the Belarusian State National Park "Belovezhskaya Pushcha" (BSNP) in 1991 [168]. The BSNP covers recently 153,000 ha, including the whole eastern part of the BF, with its foreground. For the moment it allows the avoidance of social perturbations and conflicts over forest management. As both parts of the BF compose the transboundary UNESCO World Heritage Site "Białowieża Forest" (Figure 1B), a common concerted management approach needs to be developed.

\section{Trends and Forecasts}

Palynological studies confirm that BF has been changing everlastingly [57]. This is one of the basic features of the natural forest dynamics: continual change in the proportion and composition of species 
assemblages, that assures the persistence of ecosystems [46]. The palynological data, archaeological records, and historical documents all confirm that BF was visited, settled, and used by humans in prehistoric and historic times. However, its transitional location between Central and Eastern Europe, from both a biogeographic and climatologic point of view [46], as well as from the cultural and political point of view [169], have resulted in its marginal location in relation to the centres of any developing cultures [170]. Thus, settlement density was here distinctly lower than in most of the Central European Lowland. Periods of relatively higher settlement activity, in the early and late Iron Age, were followed by several centuries of untraceable or very weak human activity, allowing forest regeneration. Even in medieval times settlement was still rather sparse, having only a local impact on the forest, as suggested by the very slight palynological signature of humans $[57,118]$. The main difference in the level of preservation of BF in comparison to other Central European forests is an effect of the unique system of protection lasting for more than 500 years, from the end of the 14th to the 19th centuries [145,149]. The long-lasting prohibition on settling and agriculture inside the forest, the regulation and limitation of all types of forest use, and the lack of artificial forest planting and 19th-century management towards conservation of bison all resulted in the preservation of the natural, iconic forest up to the beginning of the 20th century [138,145,149,153,158], fragments of which survived until the beginning of the 21st century [11]. However, current accelerating climate change, combined with trends in societal development and human environmental impacts puts further survival of this forest at risk. The climatic models for north-eastern Poland forecast an increase of temperatures, especially in the winter period, a slight increase in precipitation (by 10-20\%), and an increase of the length of the growing season in the next decades [171]. These changes will cause shifts in species ranges and dominance, which will alter interspecies interactions, and in effect will change the structure, biodiversity, and functioning of forest ecosystems. It is anticipated that in this part of Europe, especially the roles of two tree species may dramatically change: Norway spruce and European beech $[172,173]$. The contemporary natural range of beech does not cover BF, however, it is expected to expand towards the north and east [174], which means colonization of the region. Beech is highly shade tolerant and in effect very competitive to other trees [175]. Therefore, its establishment may potentially lead, in the longer time scale, to rearrangement of the BF tree stands. The situation of the Norway spruce is the opposite to beech: it has recently been one of the main components of the BF tree stands on almost all habitat types [46] but is expected to gradually decline and its natural range limit is going to shift $100 \mathrm{~km}-200 \mathrm{~km}$ towards the north and north-east [173]. This may cause the extinction of species strictly associated with spruce and the decline of those which are partly dependent on it. Thus, the forest structure, biodiversity, and function are going to change seriously, because trees are the foundation species of forest ecosystems [176,177]. The changes already have started and some are taking place in a relatively rapid way, which alerts forest managers. The share of Norway spruce had been seriously reduced in the managed part of the Polish BF during the period 2013-2018 as a result of the recent bark beetle outbreak [19]. However, in the strict reserve of the PL BNP the share of boreal tree species (e.g., Norway spruce, Scots pine) declines and species typical of temperate deciduous forests (e.g., hornbeam and small-leaved lime) expands already for several decades [178]. The other adjustments of species and communities to climate change are less obvious. It is reflects in plant and bird phenology, which follows advancing springs, starting weeks earlier than a few decades ago $[44,179,180]$. There are also warmth demanding southern species of insects, which colonised BF during the last decade, e.g., Mantis religiosa L. [119], Xylocopa valga Gerstaecker [181] and Sceliphron destillatorium Ill. [Jaroszewicz, unpubl.]. However, some taxonomic groups seem to be resistant to climate change or react with a time lag, e.g., composition of understory plant and epiphytic lichen assemblages do not show any signs of thermophilization [182,183]. 


\section{Conclusions}

The anticipated shift in forest biodiversity, structure, and dynamics yields a natural temptation to act against these changes, to save the status quo of biodiversity as we know it from our times [184-187]. However, most of the species threatened by the oncoming change are also present elsewhere and intervention usually brings side effects: further disturbs disturbed ecosystems even more deeply [188]. An active approach to management of biodiversity is inevitably associated with the conservation dilemma, that measures implemented to favour a specific threatened species or habitat will impede the conservation of other threatened species [189-191] or will bring the decline of other often neglected or unknown species. Thus, in BF-the best preserved forest ecosystem of temperate Europe-active nature conservation should be limited in space to only those places, where human-dependent species or habitats require intervention to persist.

In our intensively managed landscapes, we need to set apart some forest ecosystems (the more natural, the better) from direct human interference to allow shaping them by natural processes. We need knowledge on the natural drivers, trends, and mechanisms of change, to upgrade nature conservation and forest management towards sustainability and real multifunctionality in face of global change [192-194]. The main problem in acquisition of this knowledge lies in the fact that the reaction of managed forests to climate change is disturbed by current silvicultural actions and by the legacies of historic management $[89,90,94,188]$. This goal can be achieved only if the forest ecosystem is set aside for long enough to recover from previous forest management, and its size exceeds the minimal area needed for maintaining its natural dynamic state of equilibrium. However, we do not know what the size of such a minimal area for European temperate forest is, but we also have no place to study it, except the BF. For this reason it is extremely important to protect the whole $\mathrm{BF}$ in as natural a condition as possible [60]. We do not have any more natural forest ecosystems of this size in the temperate zone of Europe [11]. Without the possibility of resurveying ecosystems kept out of direct human management, we will be not able to understand the accelerating changes caused by global warming $[184,195]$. Therefore, we need to maintain the high naturalness of the BF and allow its self-restoration in disturbed fragments, by protecting the continuity of ecological processes.

Since the whole Belarusian part of the forest, including its foreground, is protected as a national park [18], with 58,000 ha of strict protection, the future prospects of BF depend on development in nature conservation in the Polish part. That is, where silviculture is still increasing the fragmentation and isolation of the last patches of the close-to-natural stands within human designed commercially converted stands, which depart the whole BF dangerously further from the natural state, with each year of silvicultural activity $[19,196]$. The challenges brought by climate change require the preservation of large set-aside reference areas, where processes associated with forest ecosystem resilience and adaptation to new environmental conditions can be maintained, including evolutionary processes [184]. Society and science urgently need such reference areas to study nature's inherent ability to adapt to climate change and to devise functional climate adaptation policies in managed forests [197-199]. From this point of view, $\mathrm{BF}$ is an irreplaceable living laboratory for ecological and evolutionary sciences, and should become a prime model for nature conservation and forest research, and an important benchmark for conservation science and modern forestry.

Author Contributions: B.J. conceived the idea and led the writing of the manuscript together with O.C.; All authors wrote specific parts of the manuscript (environmental history: M.L., M.Z. and T.S., biodiversity: B.J. and J.M.G., introduction and recent history: B.J. and O.C.) and contributed critically to the drafts of the whole manuscript.

Funding: The palaeoecological research reported in this study was funded by the Polish Ministry of Science and Higher Education/Polish National Science Center (project MNiSW/NCN: N N305 167839) and statutory funds of the University of Gdańsk (530-L145-D581-18). 
Acknowledgments: The authors thank Anna Pęziszewska for providing a part of the palynological unpublished data used in this publication. The development of the ideas in this paper benefited greatly from the participation of B.J. in the ALTER-Net AHIA 2018-2019 project granted to Per Angelstam “Land-sparing vs. land-sharing for functional green infrastructure that sustains biodiversity and ecosystem services?-European landscape approach initiatives provide regionally adapted solutions".

Conflicts of Interest: The authors declare no conflict of interest.

\section{References}

1. Ibisch, P. Food for forest fights. Conserv. Biol. 2018, 32, 1479-1483. [CrossRef]

2. Zeng, Z.; Gower, D.B.; Wood, E.F. Accelerating forest loss in Southeast Asian Massif in the 21st century: A case study in Nan Province, Thailand. Glob. Chang. Biol. 2018, 24, 4682-4695. [CrossRef] [PubMed]

3. Hansen, M.C.; Potapov, P.V.; Moore, R.; Hancher, M.; Turubanova, S.A.; Tyukavina, A.; Thau, D.; Stehman, S.V.; Goetz, S.J.; Loveland, T.R.; et al. High-resolution global maps of 21st- century forest cover change. Science 2013, 342, 850-853. [CrossRef] [PubMed]

4. Morales-Hidalgo, D.; Oswalt, S.N.; Somanthan, E. Status and trends in global primary forest, protected areas, and areas designated for conservation of biodiversity from the Global Forest Resources Assessment 2015. For. Ecol. Manag. 2015, 352, 68-77. [CrossRef]

5. Isbell, F.; Craven, D.; Connolly, J.; Loreau, M.; Schmid, B.; Beierkuhnlein, C.; Bezemer, T.M.; Bonin, C.; Bruelheide, H.; de Luca, E.; et al. Biodiversity increases the resistance of ecosystem productivity to climate extremes. Nature 2015, 526, 574-577. [CrossRef]

6. Crowther, T.W.; Glick, H.B.; Covey, K.R.; Bettigole, C.; Maynard, D.S.; Thomas, S.M.; Smith, J.R.; Hintler, G.; Duguid, M.C.; Amatulli, G.; et al. Mapping tree density at a global scale. Nature 2015, 525, 201-205. [CrossRef]

7. Gamfeldt, L.; Snäll, T.; Bagchi, R.; Jonsson, M.; Gustafsson, L.; Kjellander, P.; Ruiz-Jaen, M.C.; Fröberg, M.; Stendahl, J.; Philipson, C.D.; et al. Higher levels of multiple ecosystem services are found in forests with more tree species. Nat. Commun. 2013, 4, 1340. [CrossRef] [PubMed]

8. Potapov, P.; Hansen, M.C.; Laestadius, L.; Turubanova, S.; Yaroshenko, A.; Thies, C.; Smith, W.; Zhuravleva, I.; Komarova, A.; Minnemeyer, S.; et al. The last frontiers of wilderness: Tracking loss of intact forest landscapes from 2000 to 2013. Sci. Adv. 2017, 3, e1600821. [CrossRef]

9. Kaplan, J.O.; Kumhardt, K.M.; Zimmermann, N. The prehistoric and preindustrial deforestation of Europe. Quat. Sci. Rev. 2009, 28, 3016-3034. [CrossRef]

10. Dieler, J.; Uhl, E.; Bieber, P.; Müller, J.; Rötzer, T.; Pretzsch, H. Effect of forest stand management on species composition, structural diversity, and productivity in the temperate zone of Europe. Eur. J. For. Res. 2017, 136, 739-766. [CrossRef]

11. Sabatini, F.M.; Burrascano, S.; Keeton, W.S.; Levers, C.; Lindner, M.; Pötschner, F.; Verkerk, P.J.; Bauhus, J.; Buchwald, E.; Chaskovsky, O.; et al. Where are Europe's last primary forests? Divers. Distrib. 2018, 24, 1426-1439. [CrossRef]

12. Schulze, E.D.; Bouriaud, O.; Weber, U.; Roscher, C.; Hessenmoeller, D.; Kroiher, F.; Schall, P. Management breaks the natural productivity-biodiversity relationship in forests and grassland: An opinion. For. Ecosyst. $2018,5,3$. [CrossRef]

13. Handa, T.; Aerts, F.; Berendse, F.; Berg, M.P.; Bruder, A.; Butenschoen, O.; Chauvet, E.; Gessner, M.O.; Jabiol, J.; Makkonen, M.; et al. Consequences of biodiversity loss for litter decomposition across biomes. Nature 2014, 509, 218-221. [CrossRef] [PubMed]

14. Albrecht, J.; Berens, D.G.; Jaroszewicz, B.; Selva, N.; Brandl, R.; Farwig, N. Correlated loss of ecosystem services in coupled mutualistic networks. Nat. Commun. 2014, 5, 3810. [CrossRef] [PubMed]

15. Albrecht, J.; Bohle, V.; Berens, D.; Jaroszewicz, B.; Selva, N.; Farwig, N. Variation in neighbourhood context shapes frugivore-mediated facilitation and competition among co-dispersed plant species. J. Ecol. 2015, 103, 526-536. [CrossRef] 
16. Larrieu, L.; Cabanettes, A.; Gonin, P.; Lachat, T.; Paillet, Y.; Winter, S.; Bouget, C.; Deconchat, M. Deadwood and tree microhabitat dynamics in unharvested temperate mountain mixed forests: A life-cycle approach to biodiversity monitoring. For. Ecol. Manag. 2014, 334, 163-173. [CrossRef]

17. Kuuluvainen, T.; Laiho, R. Long-term forest utilization can decrease forest floor microhabitat diversity: Evidence from boreal Fennoscandia. Can. J. For. Res. 2004, 34, 303-309. [CrossRef]

18. Krzyściak-Kosińska, R.; Arnolbik, V.; Antczak, A. (Eds.) Białowieża Forest. "Belovezhskaya Pushcha/Białowieża Forest" World Heritage Site (33 BIS). Proposed Modification of the Criteria and Boundaries, Change of the Name of the Property. Nomination Dossier to the UNESCO for the Inscription on the World Heritage List. 2012. Available online: https://whc.unesco.org/en/list/33/documents/ (accessed on 28 April 2019).

19. Mikusiński, G.; Bubnicki, J.W.; Churski, M.; Czeszczewik, D.; Walankiewicz, W.; Kuijper, D.P.J. Is the impact of loggings in the last primeval lowland forest in Europe underestimated? The conservation issues of Białowieża Forest. Biol. Conserv. 2018, 227, 266-274. [CrossRef]

20. Stokstad, E. Last stands. Foresters and ecologists face off over the future of Europe's oldest forest. Science 2017, 358, 1240-1243. [CrossRef]

21. Blicharska, M.; Smithers, R.J. Białowieża Forest: Political stands. Science 2018, 359, 646. [CrossRef]

22. Goździewska, K. Puszcza bez Człowieka Zginie. Z Andrzejem Koniecznym, Wiceministrem Środowiska, Rozmawia Karolina Goździewska. Available online: http://www.naszdziennik.pl/polska-kraj/152091, puszczabez-czlowieka-zginie.html (accessed on 20 February 2016).

23. Goździewska, K. Puszcza Nie Przetrwa bez Człowieka. Rozmowa z prof. Bogdanem Brzezieckim, kierownikiem Katedry Hodowli Lasu Szkoły Głównej Gospodarstwa Wiejskiego w Warszawie. Available online: http://wp. naszdziennik.pl/2016-02-17/234419, puszcza-nieprzetrwa-bez-czlowieka.html (accessed on 20 February 2016).

24. Callaway, E.; Castelvecchi, D.; Cyranoski, D.; Gibney, E.; Ledford, H.; Lee, J.J.; Morello, L.; Phillips, N.; Schiermeier, Q.; Tollefson, J.; et al. 2017 in news: The science events that shaped the year. Nature 2017, 552, 304-307. [CrossRef] [PubMed]

25. Grant, M.J.; Booth, A. A typology of reviews: An analysis of 14 review types and associated methodologies. Health Inf. Libr. J. 2009, 26, 91-108. [CrossRef] [PubMed]

26. Web of Science. Available online: www.webofknowledge.com (accessed on 15 January 2019).

27. Karpiński, J.J.; Okołów, C. Bibliografia Białowieska [Bibliography of Białowieża]; Ministerstwo Leśnictwa i Przemysłu Drzewnego. Zarząd Ochrony Przyrody: Warszawa, Poland, 1969.

28. Okołów, C. Bibliografia Puszczy Białowieskiej 1967-1972 [Bibliography of Białowieża Forest 1967-1972]; Białowieski Park Narodowy: Białowieża, Poland, 1976.

29. Okołów, C. Bibliografia Puszczy Białowieskiej 1973-1980 [Bibliography of Białowieża Forest 1973-1980]; Białowieski Park Narodowy, Muzeum Przyrodniczo-Leśne im prof. Jana Miklaszewskiego: Białowieża, Poland, 1973.

30. Okołów, C. Bibliografia Puszczy Białowieskiej 1981-1985 [Bibliography of Białowieża Forest 1981-1985]; Białowieski Park Narodowy: Białowieża, Poland, 1991.

31. Okołów, C. Bibliografia Puszczy Białowieskiej 1986-1990 [Bibliography of Białowieża Forest 1986-1990]; Białowieski Park Narodowy: Białowieża, Poland, 1997.

32. Okołów, C. Bibliografia Puszczy Białowieskiej 1991-1995 [Bibliography of Białowieża Forest 1991-1995]; Białowieski Park Narodowy: Białowieża, Poland, 2007.

33. Okołów, C. Bibliografia Puszczy Białowieskiej 1996-2000 [Bibliography of Białowieża Forest 1996-2000]; Białowieski Park Narodowy: Białowieża, Poland, 2008.

34. Bajko, P. Bibliografia Puszczy Białowieskiej 2001-2005 [Bibliography of Białowieża Forest 2001-2005]; Białowieski Park Narodowy: Białowieża, Poland, 2008.

35. Bajko, P. Bibliografia Puszczy Białowieskiej 2006-2010 [Bibliography of Białowieża Forest 2006-2010]; Białowieski Park Narodowy: Białowieża, Poland, 2014.

36. Bajko, P. Bibliografia Puszczy Białowieskiej 2011-2015 [Bibliography of Białowieża Forest 2011-2015]; Białowieski Park Narodowy: Białowieża, Poland, 2017. 
37. Wojtanowicz, J. Zlodowacenie Warty w Polsce: Pozycja i podział stratygraficzny [Warthian glaciation in Poland: Position and stratigraphic division]. In Zlodowacenie Warty w Polsce; Harasimiuk, M., Terpiłowski, S., Eds.; Wydawnictwo Uniwersytetu Marii Curie-Skłodowskiej: Lublin, Poland, 2007; pp. 13-25.

38. Kwiatkowski, W. Krajobrazy roślinne Puszczy Białowieskiej [Vegetation landscapes of Białowieża Forest]. Phytocoenosis 1994, 6, 35-87.

39. EEA (European Environmental Agency). Biogeographical Regions in Europe. Available online: https://www.eea. europa.eu/data-and-maps/data/biogeographicalregions-europe-3 (accessed on 15 January 2019).

40. Kottek, M.; Grieser, J.; Beck, C.; Rudolf, B.; Rubel, F. World Map of the Köppen-Geiger climate classification updated. Meteorol. Z. 2006, 15, 259-263. [CrossRef]

41. Boczoń, A. Charakterystyka warunków termiczno-pluwialnych w Puszczy Białowieskiej w latach 1950-2003. [Characteristics of thermal and pluvial conditions in the Bialowieza Primeval Forest between 1950 and 2003 ]. Leśne Prace Badawcze 2006, 1, 57-72.

42. Atmeh, K.; Andruszkiewicz, A.; Zub, K. Climate change is affecting mortality of weasels due to camouflage mismatch. Sci. Rep. 2018, 8, 7648. [CrossRef] [PubMed]

43. Boczoń, A.; Kowalska, A.; Ksepko, M.; Sokołowski, K. Climate Warming and Drought in the Bialowieza Forest from 1950-2015 and Their Impact on the Dieback of Norway Spruce Stands. Water 2018, 10, 1502. [CrossRef]

44. Sparks, T.H.; Jaroszewicz, B.; Krawczyk, M.; Tryjanowski, P. Advancing phenology in Europe's last lowland primeval forest: Non-linear temperature response. Clim. Res. 2009, 39, 221-226. [CrossRef]

45. EEA (European Environmental Agency). European Forest Types. Categories and Types for Sustainable Forest Management Reporting and Policy, 2nd ed.; European Environment Agency: Copenhagen, Denmark, EEA Technical Report 09/2006; Available online: https://www.foresteurope.org/docs/other_meetings/2006/wfc/WFC_4_eea_ technical_report_92006.pdf (accessed on 15 January 2019).

46. Faliński, J.B. Vegetation Dynamics in Temperate Lowland Primeval Forests: Ecological Studies in Białowieża Forest; Dr. W. Junk Publishers: Dordrecht, The Netherlands, 1986.

47. Gutowski, J.M.; Jaroszewicz, B. (Eds.) Catalogue of the Fauna of Białowieża Primeval Forest; Instytut Badawczy Leśnictwa: Warszawa, Poland, 2001.

48. Zub, K. Mammals. In Białowieża National Park. Know it-Understand it_Protect it; Okołów, C., Karaś, M., Bołbot, A., Eds.; Białowieski Park Narodowy: Białowieża, Poland, 2009; pp. 127-142.

49. Adamowski, W. The flora of vascular plants. In Białowieża National Park. Know it-Understand it-Protect it; Okołów, C., Karaś, M., Bołbot, A., Eds.; Białowieski Park Narodowy: Białowieża, Poland, 2009; pp. 59-72.

50. Kujawa, A. The macrofungi. In Białowieża National Park. Know it-Understand it_Protect it; Okołów, C., Karaś, M., Bołbot, A., Eds.; Białowieski Park Narodowy: Białowieża, Poland, 2009; pp. 88-110.

51. Gutowski, J.M. Kózkowate (Coleoptera: Cerambycidae) wschodniej części Polski. Prace Instytutu Badawczego Leśnictwa. Seria A 1995, 811, 1-189.

52. Gutowski, J.M.; Ługowoj, J. Buprestidae (Coleoptera) of the Białowieża Primeval Forest. Polskie Pismo Entomologiczne 2000, 69, 279-318.

53. Wesołowski, T.; Jaroszewicz, B.; Kowalczyk, R.; Kujawa, A.; Gutowski, J.M. What and how to protect in the Białowieża Forest-a response to J. Hilszczański and T. Jaworski. Chrońmy Przyrodę Ojczystą 2019, 75, 51-56. (In Polish)

54. Matuszkiewicz, W.; Faliński, J.B.; Kostrowicki, A.S.; Matuszkiewicz, J.M.; Olaczek, R.; Wojterski, T. Potencjalna Roślinność Naturalna Polski. Mapa Przegladowa 1:300 000. Arkusze 1-12; IGiPZ PAN: Warszawa, Poland, 1995.

55. Gutowski, J.M.; Jaroszewicz, B. Białowieża Primeval Forest as a refuge of the European entomofauna. Wiadomości Entomologiczne 2004, 23, 67-87.

56. Tomiałojć, L.; Wesołowski, T. The avifauna of Białowie-za Forest: A window into the past. Br. Birds 2005, 98, 174-193.

57. Latałowa, M.; Zimny, M.; Pędziszewska, A.; Kupryjanowicz, M. Postglacjalna historia Puszczy Białowieskiej—roślinność, klimat i działalność człowieka. Parki Narodowe i Rezerwaty Przyrody 2016, 35, 3-49. 
58. Grzywacz, A.; Keczyński, A.; Szczepkowski, A.; Bielak, K.; Drozdowski, S.; Bolibok, L.; Brzeziecki, B. Trees of monumental sizes. In The Forests of Strict Reserve of Białowieża National Park; Keczyński, A., Ed.; Białowieża National Park: Białowieża, Poland, 2017; pp. 214-245.

59. Angelstam, P.; Dönz-Breuss, M. Measuring forest biodiversity at the stand scale-an evaluation of indicators in European forest history gradients. Ecol. Bull. 2004, 51, 305-332. Available online: https://www.jstor.org/stable/ 20113319 (accessed on 15 July 2019).

60. Wesołowski, T.; Gutowski, J.M.; Jaroszewicz, B.; Kowalczyk, R.; Niedziałkowski, K.; Rok, J.; Wójcik, J.M. Park Narodowy Puszczy Białowieskiej-Ochrona Przyrody i Rozwój Lokalnych Społeczności. [The National Park of the Białowieża Forest-Nature Conservation and Development of Local Communities]. pp. 1-28. Available online: www.forestbiology.org (accessed on 15 July 2019).

61. Tomiałojć, L. Classis (gromada): Aves-Ptaki. In Catalogue of the Fauna of Białowieża Primeval Forest; Gutowski, J.M., Jaroszewicz, B., Eds.; Instytut Badawczy Leśnictwa: Warszawa, Poland, 2001; pp. 315-325.

62. Gierczyk, B.; Ślusarczyk, T.; Szczepkowski, A.; Kujawa, A. 23th Exhibition of Fungi of the Białowieża Forest. Materials to the knowledge of mycobiota of the Białowieża Primeval Forest. Przeglad Przyrodniczy 2018, $29,9-57$.

63. Kujawa, A.; Orczewska, A.; Falkowski, M.; Blicharska, M.; Bohdan, A.; Buchholz, L.; Chylarecki, P.; Gutowski, J.M.; Latałowa, M.; Mysłajek, R.W.; et al. The Białowieża Forest-A UNESCO Natural Heritage Site-protection priorities. Leśn Prace Bad 2016, 77, 302-323. [CrossRef]

64. Hermy, M.; Honnay, O.; Firbank, L.; Grashof-Bokdam, C.; Lawesson, J.E. An ecological comparison between ancient and other forest plant species of Europe, and the implications for forest conservation. Biol. Conserv. 1999, 91, 9-22. [CrossRef]

65. Cieśliński, S. Lichens. In Białowieża National Park. Know it-Understand it_Protect it; Okołów, C., Karaś, M., Bołbot, A., Eds.; Białowieski Park Narodowy: Białowieża, Poland, 2009; pp. 73-86.

66. Faliński, J.B. The Białowieża forest, a relict ecosystem in Poland and Belarus. Biodivers. J. Life Earth 2003, 4, 18-27. [CrossRef]

67. Tomiałojć, L. Characteristics of Old Growth in the Bialowieza Forest, Poland. Nat. Areas J. 1991, 11, 7-18.

68. Sokołowski, A.W. The Flora of Vascular Plants in the Białowieża Forest; Białowieski Park Narodowy: Białowieża, Poland, 1995.

69. Pucek, Z. Mammalia-Ssaki. In Catalogue of the Fauna of Białowieża Primeval Forest; Gutowski, J.M., Jaroszewicz, B., Eds.; Instytut Badawczy Leśnictwa: Warszawa, Poland, 2001; pp. 326-328.

70. Jędrzejewska, B.; Jędrzejewski, W. Predation in Vertebrate Communities: The Białowieża Primeval Forest as a Case Study; Ecological Studies (Analysis and Synthesis); Springer: Berlin/Heidelberg, Germany, 1998; Volume 135.

71. Tomiałojć, L.; Wesołowski, T.; Walankiewicz, W. Breeding bird community of a primaeval temperate forest (Białowieża National Park, Poland). Acta Ornithol. 1984, 20, 241-310.

72. Sokołowski, A.W. Lasy Puszczy Białowieskiej; Centrum Informacyjne Lasów Państwowych: Warszawa, Poland, 2004.

73. Brzeziecki, B.; Zajączkowski, J.; Drozdowski, S.; Gawron, L.; Buraczyk, W.; Bielak, K.; Szeligowski, H.; Dzwonkowski, M.; Ostrowski, J.; Widawska, Z.; et al. Operat dynamiki ekosystemów leśnych Biatowieskiego Parku Narodowego; Szkoła Główna Gospodarstwa Wiejskiego: Warszawa, Poland, 2010; p. 209.

74. Preikša, Ž.; Brazaitis, G.; Marozas, V.; Jaroszewicz, B. Dead wood quality influences diversity of rare cryptogams in temperate broadleaved forests of Eastern Europe. iForest Biogeosci. For. 2015, 9, 276-285. [CrossRef]

75. Chećko, E.; Jaroszewicz, B.; Olejniczak, K.; Kwiatkowska-Falińska, A.J. The importance of coarse woody debris for vascular plants in temperate mixed deciduous forests. Can. J. For. Res. 2015, 45, 1154-1163. [CrossRef]

76. Wesołowski, T.; Tomiałojć, L. Breeding bird dynamics in a primaeval temperate forest: Long-term trends in Bialowieza National Park (Poland). Ecography 1997, 20, 432-453. [CrossRef]

77. Gilibert, J.E. Flora Litvanica inchoata (1781-1782); Typis S. R. M.: Grodno, Poland, 1781.

78. Gorski, S.B. O roślinach Zubrom upodobanych, jakoteż innych w puszczy Białowiezkiey. Dziennik Wileński 1829, 4, 207-217. 
79. Okołów, C. Materiały do oceny bioróżnorodności Puszczy Białowieskiej. Nowe dla nauki gatunki organizmów opisane z Puszczy Białowieskiej. Parki Narodowe i Rezerwaty Przyrody 2015, 34, 89-98.

80. Muggia, L.; Mancinelli, R.; Tønsberg, T.; Jabłońska, A.; Kukwa, M.; Palice, Z. Molecular analyses uncover the phylogenetic placement of the lichenized hyphomycetous genus Cheiromycina. Mycologia 2017, 109, 588-600. [CrossRef] [PubMed]

81. Malíček, J.; Palice, Z.; Vondrák, J.; Łubek, A.; Kukwa, M. Bacidia albogranulosa (Ramalinaceae, lichenized Ascomycota), a new sorediate lichen from European old-growth forests. MycoKeys 2018, 44, 51-62. [CrossRef]

82. Guzow-Krzemińska, B.; Łubek, A.; Kubiak, D.; Ossowska, E.; Kukwa, M. Phylogenetic approaches reveal a new sterile lichen in the genus Loxospora (Sarrameanales, Ascomycota) in Poland. Phytotaxa 2018, 348, 211-220. [CrossRef]

83. Adamowski, W.; Dvorak, L.; Ramanjuk, I. Atlas of Alien Woody Species of the Białowieża Primaeval Forest; Białowieska Stacja Geobotaniczna-Wydawn. Uniw. Warszawskiego: Białowieża, Poland, 2002; Phytocoenosis (N.S.), 14. Supplementum Cartographiae Geobotanicae 14, 1-303.

84. Faliński, J.B.; Mułenko, W. Cryptogamous Plants in the Forest Communities of Białowieża National Park; Białowieska Stacja Geobotaniczna UW: Białowieża, Poland, 1997; Phytocoenosis (N.S.) 1996, 8 Archiwum Geobotanicum 6 , $1-224$.

85. Wojewoda, W. Życie i dzieło profesora Stanisława Domańskiego (1916-1993). Wiadomości Botaniczne 1997, 41, 39-47.

86. Karasiński, D.; Wołkowycki, M. An annotated and illustrated catalogue of Polypores (Agaricomycetes) of the Białowieża Forest (NE Poland). Pol. Bot. J. 2015, 60, 217-292. [CrossRef]

87. Gutowski, J.M.; Czachorowski, S.; Górski, P.; Wanat, M. Invertebrates. In Białowieża National Park. Know it-Understand it-Protect it; Okołów, C., Karaś, M., Bołbot, A., Eds.; Białowieski Park Narodowy: Białowieża, Poland, 2009; pp. 161-176.

88. Ratcliffe, S.; Wirth, C.; Jucker, T.; van der Plas, F.; Scherer-Lorenzen, M.; Verheyen, K.; Allan, E.; Benavides, R.; Bruelheide, H.; Ohse, B.; et al. Biodiversity and ecosystem functioning relations in European forests depend on environmental context. Ecol. Lett. 2017, 20, 1414-1426. [CrossRef] [PubMed]

89. Motzkin, G.; Wilson, P.; Foster, D.R.; Allen, A. Vegetation patterns in heterogeneous landscapes: The importance of history and environment. J. Veg. Sci. 1999, 10, 903-920. [CrossRef]

90. Donohue, K.; Foster, D.R.; Motzkin, G. Effects of the past and the present on species distribution: Land-use history and demography of wintergreen. J. Ecol. 2003, 88, 303-316. [CrossRef]

91. De Castro Solar, R.R.; Barlow, J.; Ferreira, J.; Berenguer, E.; Lees, A.C.; Thomson, J.R.; Louzada, J.; Maués, M.; Moura, N.G.; Oliveira, V.H.F.; et al. How pervasive is biotic homogenization in human-modified tropical forest landscapes? Ecol. Lett. 2015, 18, 1108-1118. [CrossRef]

92. Koerner, W.; Dupouey, J.L.; Dambrine, E.; Benoit, M. Influence of past land use on the vegetation and soils of present day forest in the Vosges mountains, France. J. Ecol. 1997, 85, 351-358. [CrossRef]

93. Hermy, M.P.; van den Bremt, P.; Tack, G. Effects of site history on woodland vegetation. In European Forest Reserves; Broekmeyer, M.E.A., Vos, W., Koop, H., Eds.; Pudoc Scientific: Wageningen, The Netherlands, 1993; pp. 219-232.

94. Franklin, J.F.; Lindenmayer, D.; MacMahon, J.; McKee, A.; Magnuson, J.; Perry, D.; Waide, R.B.; Foster, D. Threads of continuity: Ecosystem disturbance, recovery, and theory of biological legacies. Conserv. Biol. Pract. 2000, 1, 8-16. [CrossRef]

95. Krasnodębski, D.; Olczak, H. Badania archeologiczne na terenie polskiej części Puszczy Białowieskiej—stan obecny, problemy i perspektywy. Biuletyn Konserwatorski Województwa Podlaskiego 2012, 18, 145-168.

96. Prusinkiewicz, Z.; Michalczuk, C. Gleby Białowieskiego Parku Narodowego; Białowieska Stacja Geobotaniczna UW: Białowieża, Poland, 1998; Phytocoenosis (N.S.), 10 Supplementum Cartographiae Geobotanice 10, 1-40.

97. Lindenmayer, D.B.; Laurance, W.F. The ecology, distribution, conservation and management of large old trees. Biol. Rev. 2017, 92, 1434-1458. [CrossRef] 
98. Lindenmayer, D.B.; Laurance, W.F.; Franklin, J.F. Global Decline in Large Old Trees. Science 2012, 338, 1305-1306. [CrossRef]

99. Lutz, J.A.; Larson, A.J.; Swanson, M.E.; Freund, J.A. Ecological importance of large-diameter trees in a temperate mixed-conifer forest. PLoS ONE 2012, 7, e36131. [CrossRef] [PubMed]

100. Foster, D.R.; Knight, D.H.; Franklin, J.F. Landscape Patterns and Legacies Resulting from Large, Infrequent Forest Disturbances. Ecosystems 1998, 1, 497-510. [CrossRef]

101. Abs, C.; Fischer, A.; Faliński, J.B. Vegetationsőkologischer Vergleich von Naturwald und Wirtschftswald, dargestellt am Beispiel des Tilio-Carpinetum im Waldgebiet von Bialowieza/Nordost-Polen. Forstwissenschaftliches Centralblatt Vereinigt Mit Tharandter Forstliches Jahrbuch 1999, 118, 181-196.

102. Pucek, Z.; Jędrzejewski, W.; Jędrzejewska, B.; Pucek, M. Rodent population dynamics in a primeval deciduous forest (Białowieża National Park) in relation to weather, seed crop, and predation. Acta Theriol. 1993, 38, $199-232$. [CrossRef]

103. Stenseth, N.C.; Viljugrain, H.; Jędrzejewski, W.; Mysterud, A.; Pucek, Z. Population dynamics of Clethrionomys glareolus and Apodemus flavicollis: Seasonal components of density dependence and density independence. Acta Theriol. 2002, 47, 39-67. [CrossRef]

104. Bogdziewicz, M.; Zwolak, R.; Crone, E.E. How do vertebrates respond to mast seeding? Oikos 2016, 125, 300-307. [CrossRef]

105. Gutowski, J.M.; Jaroszewicz, B. Zmiany udziału świerka pospolitego w drzewostanach Puszczy Białowieskiej w kontekście dynamiki liczebności kornika drukarza Ips typographus (L.). [Changes in the abundance of Norway spruce in stands of Białowieża Forest in the context of dynamics of spruce bark beetle Ips typographus (L.) numbers.]. In Stan Ekosystemów Leśnych Puszczy Białowieskiej. Materiały Ogólnopolskiej Konferencji Naukowej Ministerstwa Środowiska i Generalnej Dyrekcji Lasów Państwowych, Warszawa, 28 października 2015; Centrum Informacyjne Lasów Państwowych: Warszawa, Poland, 2016; pp. 87-108.

106. Wesołowski, T.; Rowiński, P. Tree defoliation by winter moth Operophtera brumata L. during an outbreak affected by structure of forest landscape. For. Ecol. Manag. 2006, 221, 299-305. [CrossRef]

107. Cornulier, T.; Yoccoz, N.G.; Bretagnolle, V.; Brommer, J.E.; Butet, A.; Ecke, F.; Elston, D.A.; Framstad, E.; Henttonen, H.; Hörnfeldt, B.; et al. Europe-wide dampening of population cycles in keystone herbivores. Science 2013, 340, 63-66. [CrossRef]

108. Jakoby, O.; Lischke, H.; Wermelinger, B. Climate change alters elevational phenology patterns of the European spruce bark beetle (Ips typographus). Glob. Chang. Biol. 2019. [CrossRef]

109. Gimmi, U.; Poulter, B.; Wolf, A.; Portner, H.; Weber, P.; Bürgi, M. Soil carbon pools in Swiss forests show legacy effects from historic forest litter raking. Landsc. Ecol. 2013, 28, 835-846. [CrossRef]

110. Maes, S.L.; Blondeel, H.; Perring, M.P.; Depauw, L.; Brümelis, G.; Brunet, J.; Decocq, G.; den Ouden, J.; Härdtle, W.; Hédl, R.; et al. Litter quality, land-use history, and nitrogen deposition effects on topsoil conditions across European temperate forests. For. Ecol. Manag. 2019, 433, 405-418. [CrossRef]

111. Mausolf, K.; Härdtle, W.; Jansen, K.; Delory, B.M.; Hertel, D.; Leuschner, C.; Temperton, V.M.; von Oheimb, G.; Fichtner, A. Legacy effects of land-use modulate tree growth responses to climate extremes. Oecologia 2018, 187, 825-837. [CrossRef]

112. Milecka, K.; Noryśkiewicz, A.M.; Kowalewski, G. History of the Białowieża Primeval Forest, NE Poland. Stud. Quat. 2009, 26, 25-39.

113. Paszewski, A. Dalsze badania nad historią lasów Puszczy Białowieskiej na podstawie analizy pyłkowej torfowisk. Roczniki Nauk Rolniczych i Leśnych 1937, 36, 183-187.

114. Paszewski, A.; Poznański, F. Materiały do historji lasów Puszczy Białowieskiej. Roczniki Nauk Rolniczych i Leśnych 1936, 36, 58-67.

115. Borowik-Dąbrowska, M.; Dabrowski, M.J. Naturalne i antropogeniczne zmiany roślinności Białowieskiego Parku Narodowego. Archeologia Polski 1973, 18, 181-200. 
116. Dąbrowski, M.J. Późnoglacjalna i holoceńska historia lasów Puszczy Białowieskiej. Część I. Białowieski Park Narodowy. Acta Soc. Bot. Pol. 1959, 28, 197-217. [CrossRef]

117. Mitchell, F.J.G.; Cole, E. Reconstruction of long-term successional dynamics of temperate woodland in Białowieża Forest, Poland. J. Ecol. 1998, 86, 1042-1059. [CrossRef]

118. Latałowa, M.; Zimny, M.; Jędrzejewska, B.; Samojlik, T. Białowieża Primeval Forest: A 2000-year Interplay of Environmental and Cultural Forces in Europe's Best Preserved Temperate Woodland. In Europe's Changing Woods and Forests: From Wildwood to Cultural Landscapes; Kirby, K.J., Watkins, C., Eds.; CAB International: Wallingford, UK, 2015; pp. 243-264.

119. Zieliński, D.; Schwarz, C.J.; Ehrmann, R. Evaluation of the expansion of Mantis religiosa (L.) in Poland based on a questionnaire survey. Anim. Biodiver. Conserv. 2018, 41, 275-280. [CrossRef]

120. Zimny, M.; Latałowa, M.; Pędziszewska, A. The Late-Holocene history of forests in the Strict Reserve of Białowieża National Park. In The Forests of the Strict Reserve of Białowieża National Park; Keczyński, A., Ed.; Białowieża National Park: Białowieża, Poland, 2017; pp. 29-59.

121. Giesecke, T.; Brewer, T.; Finsiger, W.; Leydet, M.; Bradshaw, R.H.W. Patterns and dynamics of European vegetation change over the last 15,000 years. J. Biogeogr. 2017, 44, 1441-1456. [CrossRef]

122. Normand, S.; Ricklefs, R.E.; Skov, E.; Bladt, J.; Tackenberg, O.; Svenning, J.C. Postglacial migration supplements climate in determining plant species ranges in Europe. Proc. R. Soc. B Biol. Sci. 2011, 278, 3644-3653. [CrossRef]

123. Theuerkauf, M.; Bos, J.A.A.; Jahns, S.; Janke, W.; Kuparinen, A.; Stebich, M.; Joosten, H. Corylus expansion and persistent openness in the early Holocene vegetation of northern central Europe. Quat. Sci. Rev. 2014, 90, 183-198. [CrossRef]

124. Giesecke, T.; Bennett, K.D.; Birks, H.J.B.; Bjune, A.E.; Bozilova, E.; Feurdean, A.; Finsinger, W.; Froyd, C.A.; Pokorný, P.; Rösch, M.; et al. The pace of Holocene vegetation change-testing for synchronous developments. Quat. Sci. Rev. 2011, 30, 2805-2814. [CrossRef]

125. Litt, T.; Schölzel, C.; Kúhl, N.; Brauer, A. Vegetation and climate history in the Westeifel Volcanic Field (Germany) during the past 11000 years based on annually laminated lacustrine maar sediments. Boreas 2009, 38, 679-690. [CrossRef]

126. Ralska-Jasiewiczowa, M.; Nalepka, D.; Goslar, T. Some problems of forest transformation at the transition to the oligocratic Homo sapiens phase of the Holocene interglacial in northern lowlands of central Europe. Veg. Hist. Archaeobot. 2003, 12, 233-248. [CrossRef]

127. Schmidt-Vogt, H. Die Fichte. Band I: Taxonomie_Verbreitung-Morphologie_Waldgesellschaften; Paul Parey: Hamburg, Germany; Berlin, Germany, 1977.

128. Gałka, M.; Tobolski, K.; Zawisza, E.; Goslar, T. Postglacial history of vegetation, human activity and lake-level changes at Jezioro Linówek in northeast Poland, based on multi-proxy data. Veg. Hist. Archaeobot. 2014, 23, 123-152. [CrossRef]

129. Behre, K.E. The interpretation of anthropogenic indicators in pollen diagrams. Pollen et Spores 1981, 23, $225-245$.

130. Wawrusiewicz, A. Okres neolitu i wczesnej epoki brązu na Podlasiu, stan i perspektywy badań. In Na Rubieży Kultur. Badania nad Okresem Neolitu i Wczesna Epoka Brazu; Stankiewicz, U., Wawrusiewicz, A., Eds.; Muzeum Podlaskie w Białymstoku: Białystok, Poland, 2011; pp. 13-36.

131. Tkachov, O. Preliminary results of archaeological research of the Stone Age and Bronze Age sites within the area of Białowieża Forest. In Na Rubieży Kultur. Badania nad Okresem Neolitu i Wczesna Epoka Brazu; Stankiewicz, U., Wawrusiewicz, A., Eds.; Muzeum Podlaskie w Białymstoku: Białystok, Poland, 2011; pp. 229-236.

132. Jaskanis, J. Wodzowskie Kurhany Kultury Wielbarskiej na Podlasiu; Muzeum Podlaskie w Białymstoku: Białystok, Poland, 2012.

133. Jażdżewski, K. O kurhanach nad górną Narwią i o hutnikach sprzed 17 wieków. Z Otchłani Wieków 1939, 14, 2-22.

134. Olczak, H.; Krasnodębski, K.; Samojlik, T.; Jędrzejewska, B. An iron producing settlement of the hatched pottery culture at the Berezowo Clearing in the Białowieża Forest. Wiadomości Archeologiczne 2018, 69, 149-176.

135. Samojlik, T. Bog iron ore extraction sites in the Białowieża Primeval Forest in the 17th-18th centuries. Kwartalnik Historii Kultury Materialnej 2009, 57, 399-411. 
136. Wawrzyniuk, J.; Budziszewski, J.; Jakubczak, M.; Rutyna, M.; Szlązak, R.; Szubski, M.; Urbańczyk, P. Dziedzictwo kulturowe Puszczy Białowieskiej-Wstępne rozpoznanie. Archeologica Hereditas 2017, 8, 193-200.

137. Zapłata, R.; Stereńczak, K. Puszcza Białowieska, LIDAR i dziedzictwo kulturowe-Zagadnienia wprowadzające. Raport 2016, 11, 239-255.

138. Samojlik, T. Anthropogenic changes of the environment of Białowieża Primeval Forest until the end of the 18th century. Ph.D. Thesis, Mammal Research Institute PAS, Białowieża, Poland, 2007; p. 181.

139. Samojlik, T. Traditional utilisation of Białowieża Primeval Forest (Poland) in the 15th to 18th centuries. Landsc. Archaeol. Ecol. 2010, 8, 150-164.

140. Hedemann, O. L'histoire de la Foret de Białowieża (Jusqu'a 1798); Instytut Badawczy Lasów Państwowych: Warsaw, Poland, 1939; Rozprawy i Sprawozdania Seria A, Nr 1.

141. Samojlik, T.; Rotherham, I.; Jędrzejewska, B. Quantifying historic human impacts on forest environments: A case study in Białowieża Forest, Poland. Environ. Hist. 2013, 18, 576-602. [CrossRef]

142. Daszkiewicz, P.; Jędrzejewska, B.; Samojlik, T. Puszcza Białowieska w Pracach Przyrodników 1721-1831; Wydawnictwo Naukowe Semper: Warszawa, Poland, 2004.

143. Daszkiewicz, P.; Samojlik, T.; Jędrzejewska, B. Puszcza Białowieska w Pracach Przyrodników i Podróżników 1831-1863; Wydawnictwo Naukowe Semper: Warszawa, Poland, 2012.

144. Sahanowicz, H. Historia Białorusi od Czasów Najdawniejszych do Końca XVIII Wieku; Instytut Europy Środkowo-Wschodniej: Lublin, Poland, 2002; pp. 1-411.

145. Samojlik, T.; Rotherham, I.D.; Jędrzejewska, B. The cultural landscape of royal hunting gardens from the fifteenth to the eighteenth century in Białowieża Primeval Forest. In Cultural Severance and the Environment; Rotherham, I.D., Ed.; Springer: Dordrecht, The Netherlands, 2013; pp. 191-204.

146. Samojlik, T.; Jędrzejewska, B.; Krasnodębski, D.; Olczak, H. Dwór łowiecki Wazów w Białowieży w świetle dokumentów źródłowych i badań archeologicznych. Kwartalnik Historii Kultury Materialnej 2014, 62, 73-90.

147. Samojlik, T.; Jędrzejewska, B. Utilization of Białowieża Forest in the times of Jagiellonian dynasty and its traces in the contemporary forest environment. Sylwan 2004, 148, 37-50.

148. Cook, E.R.; Seager, R.; Kushnir, Y.; Briffa, K.R.; Büntgen, U.; Frank, D.; Krusic, P.; Tegel, W.; Van der Schrier, G.; Andreu-Hayles, L.; et al. Old World megadroughts and pluvials during the Common Era. Sci. Adv. 2015, 1, e1500561. [CrossRef] [PubMed]

149. Samojlik, T.; Jędrzejewska, B.; Michniewicz, M.; Krasnodębski, D.; Dulinicz, M.; Olczak, H.; Karczewski, A.; Rotherham, I. Tree species used for low-intensity production of charcoal and wood-tar in the 18th-century Białowieża Primeval Forest, Poland. Phytocoenologia 2013, 43. [CrossRef]

150. Samojlik, T. The rise and fall of the potash industry in the Białowieża Primeval Forest in the 17th-19th centuries. Rocznik Polskiego Towarzystwa Dendrologicznego 2016, 64, 9-19.

151. Niklasson, M.; Zin, E.; Zielonka, T.; Feijen, M.; Korczyk, A.F.; Churski, M.; Samojlik, T.; Jędrzejewska, B.; Gutowski, J.M.; Brzeziecki, B. A 350-year tree-ring fire record from Białowieża Primeval Forest, Poland: Implications for Central European lowland fire history. J. Ecol. 2010, 98, 1319-1329. [CrossRef]

152. Kartsov, G. Belovezhskaya Pushcha. Eya istoricheskii ocherk, sovremennoe okhotniche khozaistvo $i$ Vysochaishie okhoty v Puchche; A. Marks: Saint Petersburg, Russia, 1903.

153. Samojlik, T.; Fedotova, A.; Niechoda, T.; Rotherham, I.D. Culturally modified trees or wasted timber: Different approaches to marked trees in Poland's Białowieża Forest. PLoS ONE 2019, 14, e211025. [CrossRef] [PubMed]

154. Samojlik, T.; Fedotova, A.; Kuijper, D.P.J. Transition from traditional to modern forest management shaped the spatial extent of cattle pasturing in Białowieża Primeval Forest in the nineteenth and twentieth centuries. Ambio 2016, 45, 904-918. [CrossRef]

155. Paczoski, J. Lasy Białowieży; Państwowa Rada Ochrony Przyrody: Poznań, Poland, 1930.

156. Kocan, T. Szkodliwe wypasy w Puszczy Białowieskiej. Przyroda Polska 1957, 1, 6-7.

157. Faliński, J.B. Antropogeniczna Roślinność Puszczy Białowieskiej Jako Wynik Synantropizacji Naturalnego Kompleksu Leśnego [Anthropogenic Vegetation of Białowieża Primeval Forest as a Result of Synanthropization of the Forest]; Państwowe Wydawnictwo Naukowe: Warszawa, Poland, 1966. 
158. Samojlik, T.; Fedotova, A.; Borowik, T.; Kowalczyk, R. Historical data on European bison management in Białowieża Primeval Forest can contribute to a better contemporary conservation of the species. Mammal Res. 2019. [CrossRef]

159. Więcko, E. Puszcza Białowieska [The Białowieża Forest]; PWN: Warszawa, Poland, 1984.

160. Mikusińska, A.; Zawadzka, B.; Samojlik, T.; Jędrzejewska, B.; Mikusiński, G. Quantifying landscape change during the last two centuries in Białowieża Primeval Forest. Appl. Veg. Sci. 2013, 16, 217-226. [CrossRef]

161. Jędrzejewska, B.; Jędrzejewski, W.; Bunevich, A.N.; Miłkowski, L.; Krasiński, Z.A. Factors shaping population densities and increase rates of ungulates in Białowieża Primeval Forest (Poland and Belarus) in the 19th and 20th century. Acta Theriol. 1997, 42, 399-451. [CrossRef]

162. Kuijper, D.P.J.; Jędrzejewska, B.; Brzeziecki, B.; Churski, M.; Jędrzejewski, W.; Żybura, H. Fluctuating ungulate density shapes tree recruitment in natural stands of the Białowieża Primeval Forest, Poland. J. Veg. Sci. 2010, 21, 1082-1098. [CrossRef]

163. Keczyński, A. Regeneracja grądu Tilio-Carpinetum Tracz. 1962 w następstwie dawnego użytkowania lasu w Białowieskim Parku Narodowym. Sylwan 2007, 151, 58-65.

164. Bobiec, A.; Jaszcz, E.; Wojtunik, K. Oak (Quercus robur L.) regeneration as a response to natural dynamics of stands in European hemiboreal zone. Eur. J. For. Res. 2011, 130, 785-797. [CrossRef]

165. Pączewski, L. Lasy, Przemyst i Handel Drzewny w Polsce [Forests, Industry and Timber Trade in Poland]; Instytut wydawniczy Bibljoteka Polska: Warszawa, Poland, 1924.

166. European Court of Justice Judgment of the Court (Grand Chamber) of 17 April 2018. European Commission vs. Republic of Poland. Case C-441/17. Available online: https:/eur-lex.europa.eu/legalcontent/EN/ALL/?uri= CELEX:62017CJ0441 (accessed on 17 April 2019).

167. Szafer, W. Pierwsze karty z historii Białowieskiego Parku Narodowego [The first chapters of the history of Białowieża National Park]. Kosmos 1957, 5, 468-475.

168. Kavalenia, A.A.; Danilovich, V.V.; Dounar, A.B.; Zhylinski, M.G.; Kalechits, A.G.; Litvin, A.M.; Lysenka, P.F.; Liauko, V.M.; Nichyparovich, S.A.; Stashkevich, A.I. (Eds.) Belavezhskaia Pushcha. Vytoki Zapavednastsi. Gistoria $i$ Suchasnasts; Belaruskaia Navuka: Minsk, Belarus, 2009.

169. Barwiński, M. Podlasie jako region pogranicza. Studia z Geografii Politycznej i Historycznej 2014, 3, $281-306$.

170. Kaczanowski, P.; Kozłowski, J.K. Najdawniejsze Dzieje Ziem Polskich; Forga Oficyna Wydawnicza: Kraków, Poland, 1998.

171. Liszewska, M. Klimat w Polsce w XXI wieku—Prawdopodobne kierunki zmian; perspektywa klimatów lokalnych. In Materiały Pierwszego Panelu Ekspertów w Ramach prac nad Narodowym Programem Leśnym: Klimat-Lasy i Drewno a Zmiany Klimatyczne: Zagrożenia i Szanse; Rykowski, K., Ed.; Instytut Badawczy Leśnictwa: Sękocin Stary, Poland, 2014; pp. 35-44.

172. Szwagrzyk, J. Prawdopodobne zmiany zasięgów występowania gatunków drzewiastych-konsekwencje dla hodowli lasu. In Materiały Pierwszego Panelu Ekspertów w Ramach prac nad Narodowym Programem Leśnym. Klimat. Lasy i Drewno a Zmiany Klimatyczne: Zagrożenia i Szanse; Rykowski, K., Ed.; Instytut Badawczy Leśnictwa: Sękocin Stary, Poland, 2014; pp. 45-54.

173. Dyderski, M.; Paź, S.; Frelich, L.E.; Jagodziński, A.M. How much does climate change threaten European forest tree species distributions? Glob. Chang. Biol. 2018, 24, 1150-1163. [CrossRef] [PubMed]

174. Kramer, K.; Degen, B.; Buschbom, J.; Hickler, T.; Thuiller, W.; Sykes, M.T.; de Winter, W.; Van der Werf, B. Modeling exploration of the future of European beech (Fagus sylvatica L.) under climate change-range, abundance, genetic diversity and adaptive response. For. Ecol. Manag. 2010, 259, 2213-2222. [CrossRef]

175. Houston, D.T.; de Rigo, D.; Caudullo, G. Fagus sylvatica in Europe: Distribution, habitat, usage and threats. In European Atlas of Forest Tree Species; San-Miguel-Ayanz, J., de Rigo, D., Caudullo, G., Houston, D.T., Mauri, A., Eds.; Publication Office of the European Union: Luxembourg, 2016; pp. 94-95.

176. Ellison, A.M.; Bank, S.M.; Clinton, B.D.; Colburn, E.A.; Elliott, K.; Ford, C.R.; Foster, D.R.; Kloeppel, B.D.; Knoepp, J.D.; Lovett, G.M.; et al. Loss of foundation species: Consequences for the structure and dynamics of forested ecosystems. Front. Ecol. Environ. 2005, 3, 479-486. [CrossRef] 
177. Ellison, A.M.; Buckley, H.L.; Case, B.S.; Cardenas, D.; Duque, Á.J.; Lutz, J.A.; Myers, J.A.; Orwig, D.A.; Zimmerman, J.K. Species Diversity Associated with Foundation Species in Temperate and Tropical Forests. Forests 2019, 10, 128. [CrossRef]

178. Bernadzki, E.; Bolibok, L.; Brzeziecki, B.; Zajączkowski, J.; Żybura, H. Compositional dynamics of natural forests in the Bialowieza National Park, northeastern Poland. J. Veg. Sci. 2009, 9, 229-238. [CrossRef]

179. Mitrus, C.; Sparks, T.; Tryjanowski, P. First evidence of phenological change in a transcontinental migrant overwintering in the Indian sub-continent: The Red-breasted Flycatcher Ficedula parva. Ornis Fenn. 2005, 82, 13-19.

180. Wesołowski, T.; Cholewa, M. Climate variation and bird breeding seasons in a primeval temperate forest. Clim. Res. 2009, 38, 199-208. [CrossRef]

181. Huflejt, T.; Gutowski, J.M. Xylocopa valga (Hymenoptera: Apidae) w Polsce. Leśn Prace Bad 2016, 77, 341-351. [CrossRef]

182. Bernhardt-Römermann, M.; Baeten, L.; Craven, D.; De Frenne, P.; Hédl, R.; Lenoir, J.; Bert, D.; Brunet, J.; Chudomelová, M.; Decocq, G.; et al. Drivers of temporal changes in temperate forest plant diversity vary across spatial scales. Glob. Chang. Biol. 2015, 21, 3726-3737. [CrossRef] [PubMed]

183. Łubek, A.; Kukwa, M.; Jaroszewicz, B.; Czortek, P. Changes in the epiphytic lichen biota of Białowieża Primeval Forest are not explained by climate warming. Sci. Total Environ. 2018, 643, 468-478. [CrossRef] [PubMed]

184. Müller, J.; Noss, R.F.; Thorn, S.; Bässler, C.; Leverkus, A.B.; Lindenmayer, D. Increasing disturbance demands new policies to conserve intact forest. Conserv. Lett. 2019, 12, e12449. [CrossRef]

185. Keith, H.; Vardon, M.; Stein, J.; Stein, J.; Lindenmayer, D.B. Ecosystem accounts define explicit and spatial trade-offs for managing natural resources. Nat. Ecol. Evol. 2017, 1, 1683-1692. [CrossRef]

186. Flint, C.G.; McFarlane, B.; Muller, M. Human dimensions of forest disturbance by insects: An international synthesis. Environ. Manag. 2009, 43, 1174-1186. [CrossRef] [PubMed]

187. Lindenmayer, D.B.; Foster, D.R.; Franklin, J.F.; Hunter, M.L.; Noss, R.F.; Schmiegelow, F.A.; Perry, D. Salvage harvesting policies after natural disturbance. Science 2004, 303, 1303. [CrossRef]

188. Lindenmayer, D.; Thorn, S.; Banks, S. Please do not disturb ecosystems further. Nat. Ecol. Evol. $2017,1,31$. [CrossRef] [PubMed]

189. Williams, R.; Krkošek, M.; Ashe, E.; Branch, T.A.; Clark, S.; Hammond, P.S.; Hoyt, E.; Noren, D.; Rosen, D.A.S.; Winship, A. Competing conservation objectives for predators and prey: Estimating killer whale prey requirements for Chinook salmon. PLoS ONE 2011, 6, e26738. [CrossRef]

190. Karp, D.S.; Mendenhall, C.D.; Callaway, E.; Frishkoff, L.O.; Kareiva, P.M.; Ehrlich, P.R.; Daily, G.C. Confronting and resolving competing values behind conservation objectives. Proc. Natl. Acad. Sci. USA 2015, 112, 35, 11132-11137. [CrossRef]

191. Marrs, R.H.; Galtress, K.; Tonga, C.; Cox, E.S.; Blackbird, S.J.; Heyes, T.J.; Pakeman, R.J.; Le Duc, M.G. Competing conservation goals, biodiversity or ecosystem services: Element losses and species recruitment in a managed moorland-bracken model system. J. Environ. Manag. 2007, 85, 1034-1047. [CrossRef]

192. Kuuluvainen, T. Natural variability of forests as a reference for restoring and managing biological diversity in boreal Fennoscandia. Silva Fenn. 2002, 36, 1-97. [CrossRef]

193. Landres, P.B.; Morgan, P.; Swanson, F.J. Overview of the use of natural variability concepts in managing ecological systems. Ecol. Appl. 1999, 9, 1179-1188.

194. Attiwill, P.M. The disturbance dynamics of forest ecosystems: The ecological basis for conservative management. Forest Ecol. Manag. 1994, 63, 247-300. [CrossRef]

195. Steinbauer, M.J.; Grytnes, J.A.; Jurasinski, G.; Kulonen, A.; Lenoir, J.; Pauli, H.; Rixen, C.; Winkler, M.; Bardy-Durchhalter, M.; Barni, E.; et al. Accelerated increase in plant species richness on mountain summits is linked to warming. Nature 2018, 556, 231-234. [CrossRef] [PubMed]

196. Wesołowski, T. Virtual Conservation: How the European Union is Turning a Blind Eye to Its Vanishing Primeval Forests. Conserv. Biol. 2005, 19, 1349-1358. [CrossRef] 
197. Jõgiste, K.; Jonsson, B.G.; Kuuluvainen, T.; Gauthier, S.; Moser, W.K. Forest landscape mosaics: Disturbance, restoration, and management at times of global change. Can. J. For. Res. 2015, 45. [CrossRef]

198. Halme, P.; Allen, K.A.; Aunins, A.; Bradshaw, R.H.W.; Brumelis, G.; Cada, V.; Clear, J.L.; Eriksson, A.M.; Hannon, G.; Hyvarinen, E.; et al. Challenges of ecological restoration: Lessons from forests in northern Europe. Biol. Conserv. 2013, 167, 248-256. [CrossRef]

199. Kangur, A.; Korjus, H.; Jõgiste, K.; Kiviste, A. A conceptual model of forest stand development based on permanent sample-plot data in Estonia. Scand. J. For. Res. 2005, 20, 6, 94-101. [CrossRef] 